\title{
Material Geographies of House Societies: Reconsidering Neolithic Çatalhöyük, Turkey
}

\author{
Ian Kuijt
}

This paper explores how people within Neolithic villages were connected to co-resident multi-family households, and considers the potential material footprint of multi-family households within Neolithic villages. Drawing upon data from Çatalhöyük, I suggest that Neolithic communities were organized around multiple competing and cooperating Houses, similar to House Societies, where house members resided in clusters of abutting buildings, all largely the same size and with similar internal organization. These space were deeply connected to telling the generative narratives of the House as a historical and genealogical social unit, including the lives and actions of the ancestors, and in some cases embedding them physically within the fabric of the building. Çatalhöyiuk multi-family House members decorated some important rooms with display elaboration that focused on the past, the future and the family, while the dead from the households, who in many ways were still alive and part of the ancestral House, lived beneath the floor. This study underlines that researchers need to consider social scales beyond the single-family household and consider how the multi-family House existed as an organizational foundation within Neolithic villages.

\section{Thinking about House Societies}

This essay explores the multi-family House as a concept that practically organizes biological and fictive kin across many buildings and House membership at a conceptual level. While centred on the prehistoric House as a social unit, as well as the physical structures that early agricultural peoples lived in, this discussion is embedded within the generative narratives of the House as a historical and genealogical social unit. Adopting the interpretive lens of Claude LéviStrauss' concept of House Societies (1979), researchers have considered some of the social, political and economic relationships between multiple households as a social construction, corporate body and physical entity. The term 'House' referred both to a physical entity and social construct that held property, material and immaterial wealth, and claimed membership of multiple households attached to one or more physical buildings (Kahn 2014; Robin 2003). Although LéviStrauss' original definition served as an evolutionarysocial type, the original framing has been expanded to include structural transformation, the transformation of property relations, and even the emergence of more bounded and competitive social formations. Studies of House Society have focused on Mesoamerica, Southeast Asia and the Pacific (Carsten \& Hugh-Jones 1995; Gillespie 2007; Hendon 2010; Joyce \& Gillespie 2000; Kahn 2014; Robin 2003) with further works expanding discussion to other geographical regions (e.g. Beck 2007; Borić 2007; Chesson 2003; Thomas 2015). These researchers provide insights into why, at times, House members co-resided in a substantial single building, and in other cases were distributed between multiple, dispersed, smaller-scale residences. For example, looking at a residential complex in the 'Opunohu Valley, Society Island, Kahn (2014, fig. 5) illustrates the development of an origin House with other residences spatially located downslope. Elsewhere, Borić (2008) explores select Mesolithic communities in Europe and argues that a rich and original architectural vocabulary exhibits 'the first signs of the formation of the "house society" type of social institution (sensu Lévi-Strauss)', with the later phases of the 
Neolithic continuing this practice. The variable framing of House Societies and households is not just terminological: it reflects active debates as to how different Houses may have operated as a social unit and the potential materiality of these units within varied, and at times very different, temporal and geographical case studies. As noted by Borić (2007), 'There are a number of houses in the maison of Lévi-Strauss'.

In many ways this essay explores the fuzzy lines of the multiple Houses in Lévi-Strauss' maison. Houses, comprised of single- and multi-family households, require both social and residential units with all of their attendant economic, political, ritual and social foundations. Looking at the Anatolian late PrePottery and Pottery Neolithic through the model of House Society, this study focuses on three key questions. First, how were some Near Eastern Neolithic households organized and how did they exist as part of the wider social community? Second, how did Houses express, and perhaps even enforce, certain forms of social identity and membership? Expanding upon other research (Bickle et al. 2016; Larson et al. 2015; Mills 2014; Pilloud \& Larson 2011), this paper challenges the concept of the Neolithic singlefamily household as a bounded or static entity, be it biologically or socially defined. Third, to what extent were Near Eastern late Pre-Pottery and Pottery Neolithic multi-family households materialized? Expanding upon Mills (2014) and Bloch (2010), this paper reframes the Neolithic physical and social household as an integral part of a wider social network, and considers some of the ways in which households coexisted as part of a larger House. Drawing upon data from the South and North Areas of the Neolithic site of Çatalhöyük, in central Turkey, I argue that Çatalhöyük community was organized around a series of Houses that served as a social and economic unit bound inextricably together, encompassing the singularity of individuals and the collective body through daily economic and ritual practices.

\section{Thinking about the House and the household}

The household, home, and House are important foci in contemporary and archaeological research. In many ways the term 'household' is flexible, soft on the edges, and encompasses remarkable variability (Schwede et al. 2005). In this study I frame households as task-oriented social units combining aspects of economic production and consumption, biological reproduction, co-residency at some scales, and encompassing socially constructed, symbolically meaningful groups (Byrd 1994, 642-3; Wilk \& Rathje 1982) (Table 1). Researchers have grown aware that in con- temporary villages, including a wide range of cultural case studies, household members, potentially consisting of some combination of grandparents, aunts, uncles and cousins, did not always live in the same building. Instead, it is more likely that, while community members identified and recognized each other as being members of a specific multi-family household, they often lived in non-contiguous houses. Household membership is often defined along overlapping and fluid non-material dimensions of human life (possibly including links of intimacy, kinship, co-residency, age-group, friendship, apprenticeships, and fosterage), exchange of labour and knowledge, and participation in ritual and kin networks and groups. As a broader framing, Sheets et al. (1990) identify several additional aspects of households. These include: (a) production, manifested through food systems, processing technology, and structures; (b) what they define as 'pooling', which includes storage, distribution and maintenance activities; (c) transmission of knowledge and material goods; (d) reproduction, in both biological and social senses; and (e) membership in the function of the residential group.

The household and House are contexts in which public and private worlds are defined and social boundaries are created and negotiated. In this paper I use the term House or Houses to refer to the corporate social body and estate utilizing a House Society model. When I use the term residence, building, or settlement, I am referring to individual physical structures or village that has physical remains and a material world. To Buchli (2010), the home is the domestic sphere where the basic elements of cosmology and religious life, as well as the broader understanding of political and economic life, are lived and perceived. Historically, of course, the home, house, and household have been dynamically framed around a family unit and a physical location. Several researchers (e.g. Blunt 2005; Martin 2003) illustrate that houses are places. As places they are all cultural, economic and political constructions, as well as locations of human action, experience and memory. Martin (2003) notes that places combine aspects of both a locale (a site of daily life), a location (a site with connections and relations to broader social, political and economic processes) and a sense of place (a site of affective feelings). At their base, homes are idealized locations that combine co-residency of people who share values and lifestyles, and are maintained through economic practices and notions of household membership. Homes embody emergent qualities, always becoming and always being remade by the people within them.

Different researchers, of course, use varied terms and criteria for defining social relations, the relevant 
Table 1. Neolithic social units, residency and material correlates. This table is framed around ethnographic research on Near Eastern small-scale agricultural villages employing mud-brick architecture.

\begin{tabular}{|l|l|l|l|l|}
\hline Social unit & $\begin{array}{l}\text { Scale and nature of } \\
\text { social unit }\end{array}$ & \multicolumn{1}{|c|}{$\begin{array}{c}\text { Residency } \\
\text { (primary sleeping } \\
\text { location) }\end{array}$} & \multicolumn{1}{c|}{$\begin{array}{c}\text { General materials } \\
\text { correlates }\end{array}$} & \multicolumn{1}{c|}{$\begin{array}{c}\text { Architectural material } \\
\text { correlates }\end{array}$} \\
\hline $\begin{array}{l}\text { Single-family } \\
\text { household }\end{array}$ & $\begin{array}{l}\text { Reproductive couple, } \\
\text { offspring, single or } \\
\text { widowed men and } \\
\text { woman, gendered } \\
\text { groups }\end{array}$ & $\begin{array}{l}\text { Reside in the same } \\
\text { structure }\end{array}$ & $\begin{array}{l}\text { Shared access to specific } \\
\text { lithic and pottery } \\
\text { technology and design }\end{array}$ & $\begin{array}{l}\text { Reside within one or more } \\
\text { bounded structures defined } \\
\text { by restricted entrance to a } \\
\text { single main room and } \\
\text { subsidiary smaller storage } \\
\text { spaces }\end{array}$ \\
\hline $\begin{array}{l}\text { Multi-family } \\
\text { household }\end{array}$ & $\begin{array}{l}\text { Reproductive couples, } \\
\text { offspring, parents, } \\
\text { siblings of } \\
\text { reproductive couples, } \\
\text { relations through } \\
\text { marriage, others }\end{array}$ & $\begin{array}{l}\text { Unlikely for everyone to } \\
\text { reside in the same } \\
\text { structure, but typically } \\
\text { reside near each other }\end{array}$ & $\begin{array}{l}\text { Similar access to specific } \\
\text { lithic and ceramic } \\
\text { technology and design }\end{array}$ & $\begin{array}{l}\text { Reside within multiple } \\
\text { bounded houses typically } \\
\text { abutting each other or in } \\
\text { close proximity }\end{array}$ \\
\hline Neighbourhood & $\begin{array}{l}\text { Can be composed of } \\
\text { single multi-family } \\
\text { household or multiple } \\
\text { multi-family } \\
\text { households }\end{array}$ & Not applicable & $\begin{array}{l}\text { Increased variation in } \\
\text { lithic and ceramic } \\
\text { technology and design } \\
\text { with variation between } \\
\text { multi-family households }\end{array}$ & $\begin{array}{l}\text { Spatially distinct cluster of } \\
\text { buildings within a larger } \\
\text { settlement defined by } \\
\text { roadways, alleyways, paths, } \\
\text { middens, open spaces } \\
\text { and/or walls }\end{array}$ \\
\hline
\end{tabular}

unit of analysis, and how they are, or are not, manifest on the ground (e.g. Allison 1999; Blanton 1994; Bloch 2010; Flannery 1972; 2002; Hendon 2004; 2010). Pels (2010) notes, 'It is vital to realize (a) that "house" and "household" may be different units, especially when we consider commensal and economic arrangements'. One of the challenges is that household membership is often fluid, flexible, relative, seasonably variable, and can cross-cut walls and buildings (Allison 1999; Banning 2003; Horne 1982; Kramer 1982; Pels 2010; Watson 1982). Drawing upon this awareness, Souvatzi (2007) notes that many studies assume, rather than demonstrate, the material footprints of the single-family household, and provide only a limited reflection as to how many people are considered part of the single-family household.

In some cases (Carsten 1995; McKinnon 2000; Watson 1982), members of spatially grouped singlefamily households, often dwelling in separate residential buildings, functioning as part of a larger multifamily household or House as they shared labour, food preparation tasks, childcare and other social and economic practices. The major complication is, of course, that single- or multi-family households are social units, defined in different ways through time and space, subject to demographic shifts, and based on self-identification and perceived differences within cultural contexts. In many cases, people within households live in a restricted number of buildings, organized around places to sleep, work and socialize, with areas for storage of food, tools and home furnishings, as well as a spatially defined area for cooking cen- tred on the hearth and/or an oven. In all cases, the use of interior and exterior spaces, who lives in each building and when households are occupied, are all subject to local historical and personal factors. While not always living in contiguous buildings, in general young males or females partner or marry into existing families. In terms of residency, this relationship may involve a neo-local system (constructing a new residence for the partnered couple, possibly near one set of parents, or taking over an established residence from relatives) within a core residential area, or some possible bi-local, uxorilocal or virilocal system (joining and residing with one of the partners' parents).

\section{Houses and house groups, Çatalhöyük}

Numerous studies have considered the changing organization of Neolithic households and how this reflects social organization (e.g. Baird et al. 2016; Banning 2003; 2010; Boivin 2000; Byrd 1994; Conolly 1999; Düring 2001; 2006; 2007a,b; Düring \& Marciniak 2006; Flannery 1972; 2002; Hodder \& Pels 2010; Kuijt 2000; 2001; Kuijt \& Goring-Morris 2002; Kuijt et al. 2011; Marciniak 2008; 2013; Matthews 2012; Mills 2014; Rollefson 1997; 2004; Souvatzi 2007; Wright 2014). Research by ethnographers demonstrates, of course, that the composition of the household is quite variable within and between communities or whole cultural traditions, including single-family to extended coresident multi-family households and consanguineal households. While scholars are increasingly attentive to the material dimension of households (e.g. Düring 
2007a,b; Flannery 2002; Hodder \& Pels 2010), and to an extent neighbourhoods (Düring \& Marciniak 2006; Marciniak 2008), surprisingly little research has focused on the material footprint of Houses, and how they existed as biological, economic, and social units. There is a need, in short, to understand the spatial geography of the House and related households within and between villages, and how this social geography might be linked to changing social, economic and political conditions.

Research helps us understand the spatial geography and material footprint of the Neolithic House as a multi-family household endeavour (Bloch 2010; Conolly 1999; Düring \& Marciniak 2006; Garfinkel 2006; Kuijt et al. 2011). Drawing upon archaeological data from Çatalhöyük, Level VIB in the South Area excavated by Mellaart (1967), and ongoing excavations of the North Area led by Hodder, I explore how Neolithic members of households, living in individual buildings clustered spatially, were embedded within and related through Houses. Groupings of buildings, therefore, housed (and Housed) people coresiding in spatially clustered households, connected through birth, economics and ritual practices. In brief, I argue that related multi-family households operated as Houses and served as social and economic foci within Neolithic villages. Neolithic household members were firmly embedded in larger social collectives and existed as part of larger Houses built around cooperation, food and labour sharing and ritual practices. Membership was likely framed through biologically and fictive kinship (see Larson et al. 2015; Pilloud \& Larson 2011), and with people residing in a physical grouping of buildings and rooms constructed close in time and in space.

Over the last 60 years, researchers focusing on Çatalhöyük have explored how the archaeological evidence from multiple excavation areas helps us to understand Pre-Pottery and Pottery Neolithic social organization (e.g. Bogaard et al. 2009; Conolly 1999; Düring 2007a; Hodder 2006; Mellaart 1967; Twiss 2008) (Fig. 1). Although differing as to the exact timing and terminology, the Pre-Pottery Neolithic is generally subdivided into the Pre-Pottery Neolithic A period and Pre-Pottery Neolithic B period (hereafter the PPNA and PPNB). The majority of the Çatalhöyük occupation dates to the late stages of the PPNB and early stages of the Pottery Neolithic. Previous studies (e.g. Bogaard et al. 2009; Conolly 1999; Düring 2007a; Düring \& Marciniak 2006; Twiss 2008) have investigated the household as a social unit, at times modelling Çatalhöyük social relations through the actions of individuals within single buildings with one main room, spatially organized around multiple ele- vated platforms and a series of other rooms for storage (see Hodder \& Cessford 2004) (Fig. 2). Based on the number and size of storage features within structures, as well as their relatively homogenous distribution within the broader settlements, Bogaard et al. (2009), Düring (2007a) and Twiss (2008) argue that Çatalhöyük buildings were inhabited by a single or multi-generation family. Hodder and Pels $(2010,183)$ argue that buildings were occupied by kin or 'nuclear families'. Given the restricted interior area of buildings at Çatalhöyük, Düring (2007a) argues that only a limited number of people, probably no more than five or six, could have slept inside the typical residence.

\section{Çatalhöyük South Area Level VIB: alternative research context}

Excavating between 1961 and 1965, James Mellaart uncovered the remains of over 100 well-made, and at times elaborately painted and decorated, buildings made of mud brick and wood. Guided by his stratigraphic excavations, Mellaart organized the excavated Çatalhöyük South Area buildings by levels and identified these as ranging from 0 (most recent) to XIII (oldest). To Mellaart, the horizontal layout of numerous conjoined buildings reflected a roughly contemporaneous village layout that he interpreted as a densely populated village characteristic of the Middle East (Mellaart 1967).

Since James Mellaart undertook excavations at Çatalhöyük's South Area 50 years ago, numerous researchers have commented upon the extensive remains of residential buildings, the long-term maintenance of specific buildings and the rich material record of daily life. Drawing upon Mellaart's architectural, burial and symbolic data, several researchers (e.g. Czeszewska 2013, 185; Hodder 2013; Hodder \& Pels 2010; Nakamura \& Meskell 2013) have noted a distinctive architectural transition occurring between Level VIA and B, materialized in architecture, burial practices, technology and symbolism. Mellaart defined Level VIB on the basis of architectural relationships and what he viewed as roughly contemporaneous structures. Radiocarbon dating, conducted by multiple laboratories, places the Level VIB phase to between 6500 and 6400 cal. вC (Aurenche et al. 2001; Cessford 2001; Göktük et al. 2002; Hodder 2014).

Under the direction of Ian Hodder over the last 20 years, researchers have resumed excavations at the Çatalhöyük South Area, as well as initiating new excavations at several other mound locations. Recent excavations have utilized sophisticated and advanced scientific field methods and provided new insights into Neolithic life, especially at the scale of the single building. Recent radiocarbon analysis provides a 


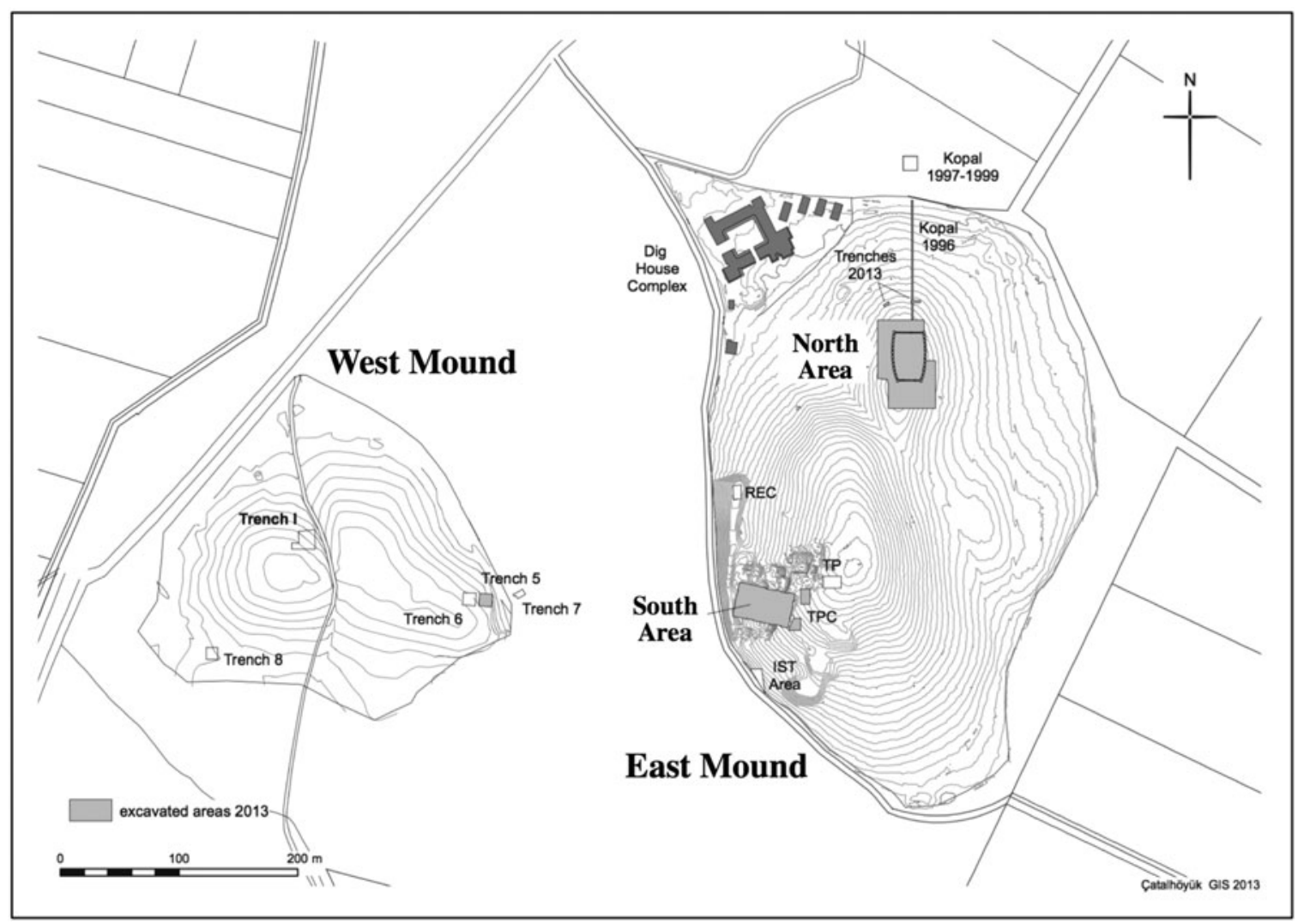

Figure 1. Major excavation areas, West and East mounds, Çatalhöyük, Turkey. (Plan: C. Mazzucato. Used by permission of Çatalhöyük Research Project.)

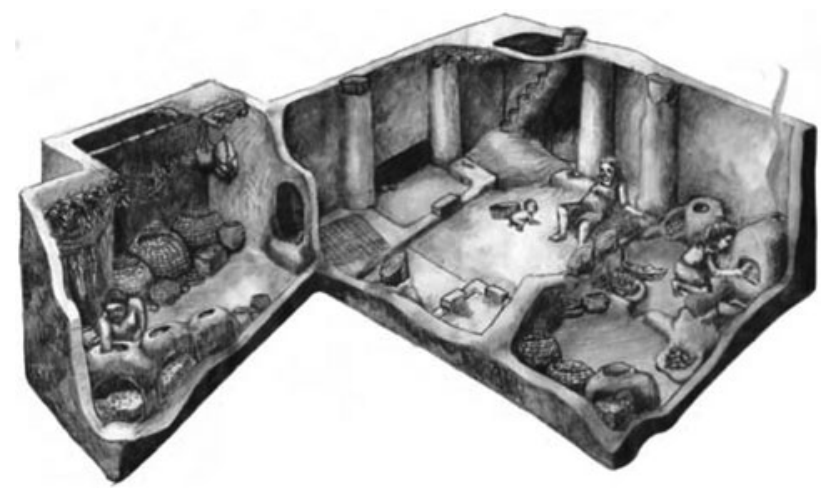

Figure 2. Reconstruction of a typical Çatalhöyük residence with platforms, benches, defined cooking areas and clay storage bins. (Reconstruction: Mesa Schumacher. Used by permission of Çatalhöyük Research Project.)

nuanced understanding of the occupational history of Çatalhöyük (Bayliss et al. 2015; Cessford 2001; Göktük et al. 2002; Marciniak et al. 2015). Bayliss et al. (2015) argue that people first started living at Çatalhöyük South Area around 7100 вс. Echoing radiocarbon re- search by Marciniak et al. (2015) in the TP area adjacent to Çatalhöyük South Area, Bayliss et al. (2015) argue that Çatalhöyük South Area was probably abandoned around $6000 \mathrm{BC}$.

Researchers (Farid 2014; Hodder 2014, table 1.1) have put forth a new occupation level scheme for Çatalhöyük with the aim of integrating architectural and material culture data from Mellaart's South Area. Under Hodder's new scheme levels, South $\mathrm{O}$ and $\mathrm{N}$ are viewed as being broadly analogous to Mellaart's level VIA and VIB and date to between 6500 and 6400 вс. Hodder's new level scheme aims to provide an accurate means of presenting a complex stratigraphic situation encountered by the current excavations, which revealed more occupational levels than originally envisioned in Mellaart's research. Additionally, it strives to scrutinize how recently excavated buildings and groups of buildings from multiple areas of Çatalhöyük are temporally equivalent to phases proposed by Mellaart. Recent research by Marciniak et al. (2015) and Bayliss et al. (2013) on Bayesian chronological modelling of the East Mound provided a richer, nuanced and more complicated 
understanding of occupational trajectories of individual buildings at Çatalhöyük. This research focused on understanding the chronology of individual features, deposits and buildings, and by extension, how they existed in time. At the same time, however, this research does not directly translate into defining synchronic groupings of buildings, nor the development of a new phasing of contiguous single structures.

This essay employs Mellaart's original level designations to discuss and compare South Area architecture and phasing (see also Czeszewska 2013). While Düring (2006) outlines the complexities in employing Mellaart's recording system this current research employs his recording system for several reasons. First, as currently defined, Hodder's level scheme does not put forth a comprehensive phasing of buildings recorded by Mellaart. The absence of a detailed comprehensive correspondence phasing of individual buildings and groupings of buildings for Çatalhöyük South Area makes it very difficult to integrate the largely diachronic research of the Hodder research team with the synchronic phasing of Mellaart. Second, important Bayesian chronological modelling is ongoing and will only become available in five or more years. Given the complexity of the stratigraphy and varying excavation methodologies over different decades, this important Bayesian chronological modelling will take time and careful review before publishing the results for individual events, features and buildings. The later integration of these results into broad phasing, cross-cutting decades of research in different excavation areas, will be even more complicated. Moreover, Bayliss et al. (2015) argue that the integration of varying data sets requires maintaining the original recording of Mellaart. For these reasons this paper employs Mellaart's building and level designations for Çatalhöyük South Area architectural phasing in order to assess synchronic relationships between physical structures, households and Houses.

\section{Çatalhöyük shrines, lineage houses and history houses}

Drawing upon architectural plans for the Çatalhöyük South Area developed by Mellaart (1967), Hodder (2013) and Düring (2006) have employed Mellaart's phasing and reconstructed horizontal village layout of Çatalhöyük South Area the better to understand household- and village-scale social organization. These studies, while differing in focus and scope, provide an initial framing of households and associated residential footprints. Mellaart (1967) argued that the Çatalhöyük architectural remains reflected spatial separation of residential and ritual practices.
Noting the clustering of bullhorns and built decorations in selected structures, he argued that Çatalhöyük people constructed two types of buildings: houses and shrines (Mellaart 1967). Mellaart's separation was based upon the frequency and visual power of wall paintings and incorporation of elaborate constructed features of animal skulls, horns placed next to hearths, benches, and grave goods found with burials. More recently, Düring $(2007 a, 165)$ argued that all buildings at Çatalhöyük were domestic residences, based upon detailed analysis of architecture, distribution of elaboration and burial practices. As outlined by Hodder (2006; 2014), there are common features of residential buildings: in general the south part of the room has a fire installation; a ladder entrance; raised benches; the room is surrounded by its own set of outer walls; and subsidiary anterooms attached to the main room, some of which contain storage bins. From this perspective, one with which I agree, the majority of buildings were used for daily residential and domestic activities.

Hodder (2014), Düring (2006) and Mellaart (1967) all generally agree on one point: the South Area buildings are of the same general size and organization, and people used the same materials and processes to construct them. Within this framework, Hodder $(2014,14)$ defines four types of Çatalhöyük buildings: elaborate buildings, multiple burial buildings, history houses, and other buildings. Hodder (2014) argues that the first three categories overlap greatly, and that to an extent, it is the variation in the commonalities that is important. He notes $(2014,14)$, for example, that elaborate houses contain more symbolism (bucrania, wild animal parts, wild animal representations, reliefs and paintings) compared to other buildings. Düring $(2006,231)$ identifies key buildings containing multiple burials and elaboration as being lineage houses, with members of interrelated households residing around a key lineage house. He suggests that approximately six households would have been associated with the social and economic unit of a lineage house. Adopting a broader framing, I interpret these clusters of households as existing as a House as per the House Society model.

As an alternative to Mellaart's (1967) framing, Hodder and Pels (2010) focus on the rebuilding of individual buildings, the association of burials and architectural elaboration with these buildings, and argue that individual buildings served as 'history houses'. The term history house refers both to an individual building as well as the larger community of people that used that building for burial. They argue $(2010,183)$ that history houses were occupied by nuclear families, had a clear diachronic ancestral 
focus and are observable through a high frequency of burials and the use of a range of architectural elaborations, such as horn benches, bucranium, platforms and painted designs. This argument is rooted in an earlier study in which Hodder and Cessford $(2004,36)$ claim there is 'a clear link between houses with many burials and houses that are replaced through many levels'.

Recent research, including by members of the Çatalhöyük research team and Hodder, raises serious questions about the intellectual framing of history houses. In their detailed statistical analysis of mortuary frequency and architecture, Carleton et al. (2013) argue there is no correlation between burial frequency and long-term rebuilding of structuresone of the central framings of history houses. Discussing the research of Nakamura and Meskell (2013), Mazzucato (2013) demonstrates that there is no correlation between burial frequency, material objects in buildings, building area, or building elaboration. In a later publication, Hodder also raises questions about the intellectual framing of history houses when he states $(2014,15)$ : 'No correlations were observed. No correlation was found between the number of burial goods and the size or elaboration of buildings'. Finally, the study of human dentition by Hillson et al. (2013) looked at the rate of growth and development in Çatalhöyük children, but found no difference between people buried in history houses and other houses. These studies raise important questions as to the distinctiveness of the people who lived in 'history houses' and the utility of the current framing of history houses.

One of the challenges in reconstructing the social geography of any prehistoric village is that researchers have an incomplete understanding of how frequently buildings and clusters of buildings were rebuilt, and their related use-life. Opinions among researchers vary widely as to the use-life of individual Neolithic buildings. As one of the higher estimates, Cessford (2005) suggests that the unfired mud-brick buildings were occupied for 70-140 years. Farid (2014, 92) offers a slightly lower estimate, arguing that the buildings were likely to have been occupied for 50 120 years. In contrast, detailed radiocarbon research by Bayliss et al. (2015) and Marciniak et al. (2015) supports the argument that many, if not the majority, of buildings from Çatalhöyük in general, and Level IVB Çatalhöyük South Area in specific, were probably used for less than 30 years. Research in the South Areas by Bayliss et al. (2015) demonstrates that the rate of formation for some middens between buildings ranged between 40 and $140 \mathrm{~cm}$ per 10 years (see also Göktük et al. 2002). Assuming this range is repre- sentative of Level IVB, then the extramural alleys and the areas between these semi-subterranean buildings would have filled up at a rate of at least $40 \mathrm{~cm}$ every 10 years. With the redeposition of sediments next to mud buildings over 10-20 years from clay washing off walls and roofs, the interior floor of buildings would eventually be below that of the exterior ground surface, thereby creating the conditions for increased moisture levels within the buildings. This erosion and infilling, as well as infestations of insects and rodents, may have created the impetus for people to rebuild their structures every $20-30$ years. Further research is clearly needed to reconcile the varied estimates for building use life, especially for different types of buildings.

\section{Bounded spaces, firehearths and burial distribution at Çatalhöyük South Area Level VIB}

Recent work at Aşikli Höyük (Düring \& Marciniak 2006), Tell Halula (Kuijt et al. 2011; Molist 1998; 2001), Boncuklu (Baird et al. 2016), Çatalhöyük (Bogaard et al. 2009; Conolly 1999; Düring 2007a; Mills 2014) and Sha'ar Hagolan (Garfinkel 2006), have drawn attention to larger-scale social units, including multi-family households. Expanding upon this foundation, I argue that a more nuanced and detailed understanding of Neolithic community organization in general, and Çatalhöyük Houses organization in specific, can be gained through a consideration of how villagers constituted their homes, the communities of practice within these communities, and how people structured daily life and ritual within and between buildings. As with Düring (2007a) and Bloch (2010), I argue (Kuijt et al. 2011) that Neolithic communities were organized similarly to House Societies. Echoing the work of Mills (2014) here I suggest that Çatalhöyük's social and ritual networks were organized by members of multi-family Houses or sodalities, centred on select buildings, that served as locations of materialized ancestry, collective memory and House identity. In brief, Houses were organized around bounded spaces, incorporated multiple residences, and were maintained through control of intergenerational material and immaterial wealth focused on ritual knowledge and practice. I argue, however, that at times House members used different spaces in varying ways, with inhabitants selecting specific rooms for burial of the dead, and identifying other spaces for ritual practices associated with built-in elaborative features. Drawing upon the material remains of fire hearths, ovens, external boundary walls, burials and decorative elaboration, I consider how Çatalhöyük Level VIB household members created spaces that connected 
household history, ancestry and House membership, with the aim of understanding human networks of single-family households, Houses and neighbourhoods. In brief, I suggest that in some villages Neolithic community was constituted around substantial multi-family Neolithic Houses that lived in spatially concentrated areas within villages. The design and location of buildings and internal features, as well as the organization of mortuary practices, provide evidence of larger multi-family households and Houses within Neolithic villages.

Creating the House: bounded spaces and terrace walls

Research focused on social network, residential patterns and kinship (Greenbaum \& Greenbaum 1985; Hipp et al. 2012; Verdery et al. 2012) illustrates, in general, that extended kin within and between villages live in closer proximity to one another than unrelated individuals. As noted by Verdery et al. (2012, 112), 'Close kin are more likely to co-reside, a fact which drives much of the relationship between kinship relatedness and dwelling unit proximity within villages'. This framing is reinforced by ethnographic research (Kramer 1982; Watson 1982) outlining that in small-scale agricultural villages single families are often interconnected through pooling of labour, food sharing and marriage, and exist as part of larger multi-family households living in multiple buildings that are relatively close to each other. Comparative archaeological research in Anatolia and the Levantine region offers additional insights and analogues into the nature of households and their material footprints. Excavations at several Neolithic villages, including 'Ain Ghazal (Banning 2003), Tell Halula (Molist 1998; 2001), Aşikli Höyük (Özbaşaran 1998; 2011), and Çatalhöyük (Brami 2017; Düring 2007a,b), demonstrate that people not only rebuilt key buildings multiple times, but that at times they rebuilt entire groups of buildings in the same location within bounded spaces. At Jericho, Aşikli Höyük and Çatalhöyük these renovations can be traced through repeated rebuilding of residences in the same location, wall abutments and the construction of buildings next to each other. Architectural data from Çatalhöyük South Area Level VIB and the North Area illustrate that people created and reused spaces defined by previously existing terrace walls and buildings.

At Çatalhöyük people created spaces and buildings that took advantage of topographical features, such as terraces on the side of the mound. Multiple researchers (Brami 2017, fig. 41; Hodder 2012, fig. 9.3; Mellaart 1967, fig. 9) have drawn upon architectural information and asserted that Çatalhöyük houses in South Area Level VIB were built on a series of ter-

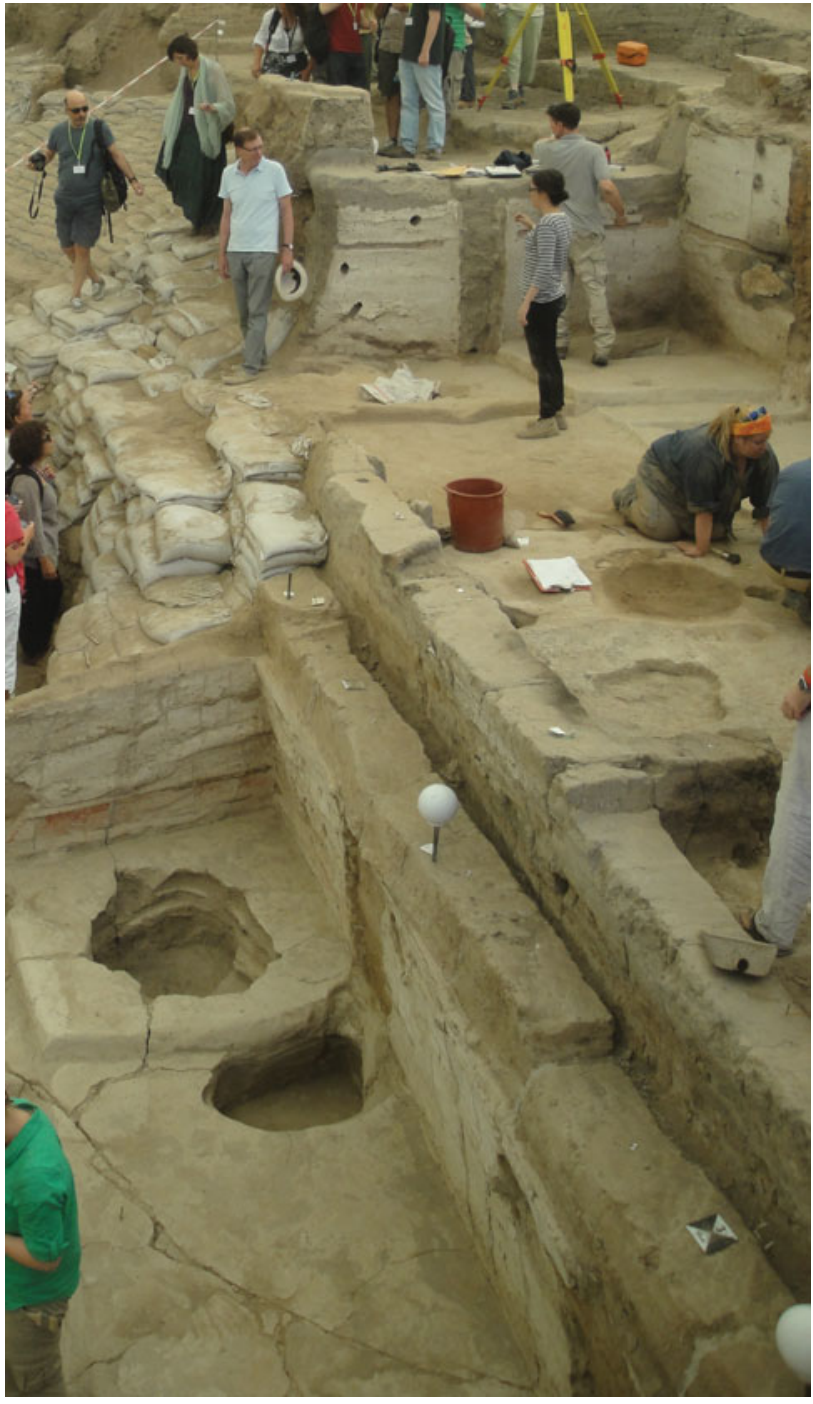

Figure 3. Photograph of abutting residential buildings, with shared building walls, along one of the north-south oriented terraces, South Area, Çatalhöyük, Turkey. The building on the eastern (right in the photograph) side is around $1.3 \mathrm{~m}$ above the lower western building.

(Photograph: I. Kuijt, 2011.)

raced areas roughly oriented north-south. These were segmented by long wall segments traversing from the upper to the lower area of the mound, thereby crosscutting the terraces and creating bounded spaces enclosing multiple buildings. The terrace areas, often surrounded by walls that were $1-1.5 \mathrm{~m}$ in height, served as foundations for multiple households and defined the eastern and western areas of habitation (see Fig. 3). There are locations, for example terrace T3 (Fig. 3), where the north-south line of the terrace is horizontally offset by about $1-2 \mathrm{~m}$, and with elevation changes of 1-1.5 m. As Hodder illustrates (2012, fig. 


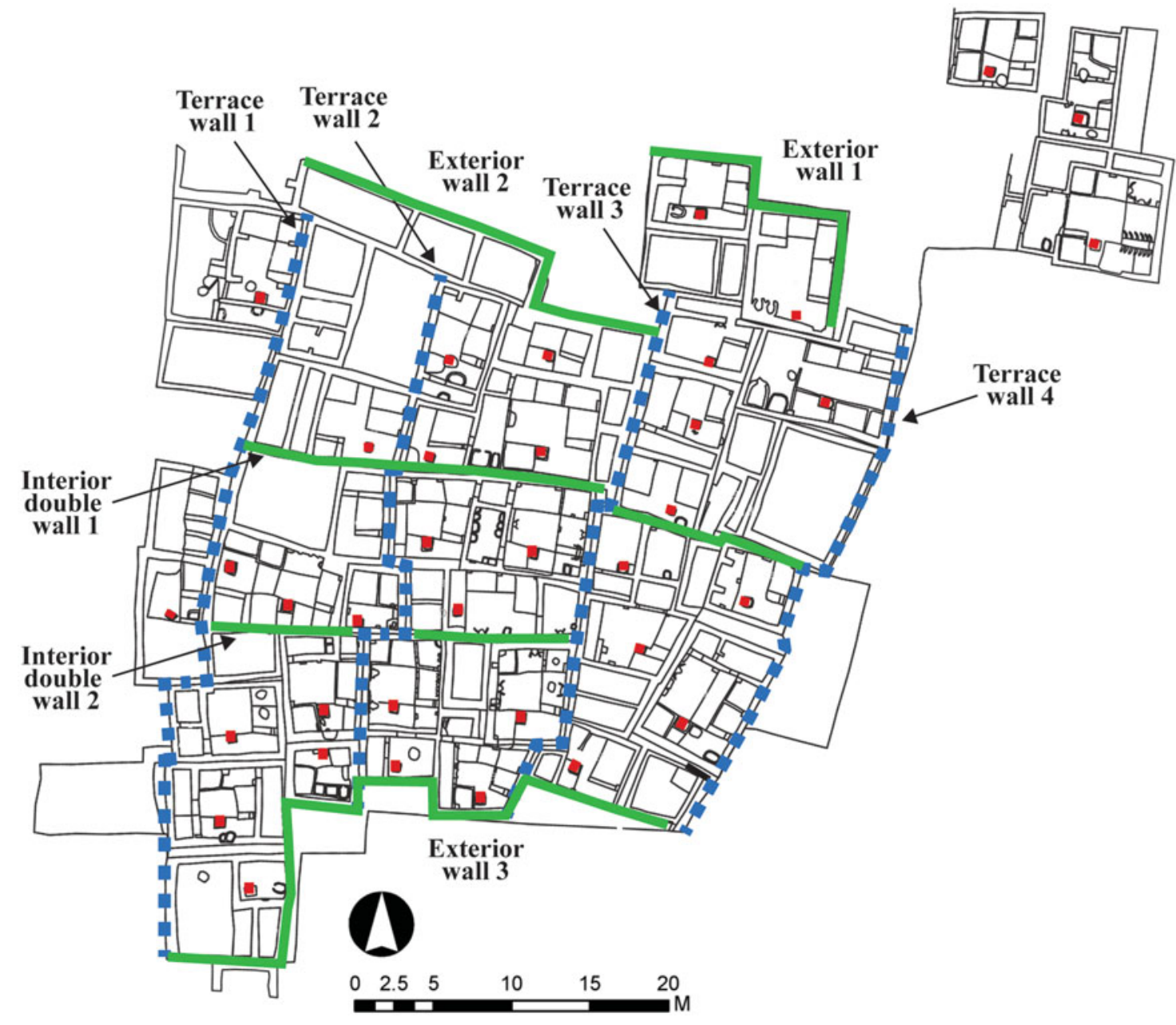

Figure 4. Location of fire hearths, terrace walls (dashed blue lines), long continuous interior double walls (IDW) and exterior walls (EW) (both solid green lines) of Level VIB, South Area, Çatalhöyük, Turkey. Note that interior double walls often cross over terrace walls seen in Fig. 3. (Based on Düring 2006, figs. 6.25 \& 6.26; Mellaart 1967, table 13.)

9.3), in many places the terracing continues over significant distances (30-40 $\mathrm{m}$ ) and provided a means by which buildings were constructed next to other buildings, at some points at an elevation above or below the floor level of neighbouring buildings.

Field research illustrates that in places these residential terraces of Çatalhöyük's South Area Level VIB were segmented by large boundary walls running east-west (Brami 2017, fig. 41; Düring 2007a; Hodder 2012; 2013; Mellaart 1967). Mellaart (1967) argues that some of these boundaries were defined by abutting buildings, thereby creating double walls where two relatively complete buildings were constructed next to each other. In discussing the phasing system of Çatalhöyük, Farid $(2014,97)$ argues that abutting wall systems help researchers group roughly contemporaneous structures into occupation levels with abutting walls built against each other at some point during the life-span of the buildings. In several places the Level VIB long abutting double walls system created bounded spaces, spaces that were repeatedly reused as a spatial area for building construction for multiple levels (Fig. 4). In some cases villagers built long exterior walls as a shared wall continuing for a significant distance $(20+\mathrm{m})$, thereby creating a bounded space where smaller houses abut at multiple angles. In addition interior double walls 1 and 2, with a general east-west orientation, served as a foundation for multiple offset small buildings constructed on the north and south sides of the wall at slightly different angles. The floor plan of many bounded spaces was renewed through later occupations. The long east-west interior double walls cross-cut the north-south-oriented terraces and continued down over several terraces in 
multiple locations, thereby creating bounded spaces for the construction of groups of buildings. In many cases these bounded spaces appear to have been built upon the footprint/ floor plan of earlier buildings and bounded spaces. Brami argues (2017, fig. 42) that similar architectural practices, with extensive terraces and radial walls, are also seen at Aşikli Höyük. I hypothesize that these bounded spaces served as core residential areas for individual Houses.

Mapping the House: food and fire hearths and 'social glue' This current study hypothesizes that Neolithic village organization in Anatolia was based on groups of single-family households that existed as part of a larger multi-family House, and that many, but not all, of these single-family households lived within core residential areas bounded by terraces, boundary walls and middens. I ague, moreover, that House members pre-identified select rooms or buildings to bury their majority of their dead, and to construct wall paintings and displays in the same or other rooms. As is outlined later, current evidence for rebuilding indicates that House members maintained and rebuilt select rooms with greater display elaboration, and that these may well have functioned as lineage houses and critical foci of display and practice related to genealogy and ancestry. In making these arguments, I weave together evidence for food preparation, the symbolic creation of ritual space and the placement of the dead within groups of buildings.

Matthews (2016) argues that the Neolithic compartmentalization of fire hearths, as well as the segregation of hearths from other select activities, was connected to wider household social-economic changes that are documented across the Near East (see also Bloch 2010; Bogaard et al. 2009). In many ways food preparation, sharing and consumption served as a form of 'social glue' within Neolithic communities (Atalay \& Hastorf 2006; Bogaard et al. 2009; Russell \& Martin 2005; Twiss 2007; 2008; 2012; Wright 2014). The practical and symbolic roles of household sharing, cooking and eating in small-scale communities would have been framed around social cooperation, shared labour in harvesting and processing, and food storage. Be it for warmth, cooking, or as a location of human contact, fire hearths serve as physical and symbolic focal points of the house and daily life (Anderson 2013; Bloch 2010; Carsten 1995, 114; Davey 2007; Ellickson 2008; Janowski 1995; Kramer 1982; Matthews 2016; Twiss 2007). Fire hearth frequency provides a methodological platform for estimating village population levels (Turner \& Lofgren 1966) and tracking households within shared larger buildings (Ames et al. 1992) and within villages (Hoffman 1999).
The spatial distribution of Neolithic fire hearths helps researchers understand the social geography of households, household membership on a practical level, and how these existed within a larger conceptual House. Looking beyond the walls of Çatalhöyük, it is important to note that at Aşikli Höyük (Özbaşaran 1998; 2011; Uzdurum 2013), where a horizontal $50 \times 70 \mathrm{~m}$ area was excavated, the remains of a Neolithic village was uncovered with houses, alleyways, courtyards and fire hearths (Fig. 5). The distribution of Aşikli Höyük fire hearths aids researchers in tracking the material footprint of households (Düring 2007a; Düring \& Marciniak 2006; Özbaşaran 1998; Uzdurum 2013). Similarly the distribution of fire hearths and ovens within Çatalhöyük South Area Level VIB residential buildings provides a means of defining the spatial location of individual households (Fairbairn et al. 2007; Mellaart 1967) (Fig. 6). Ovens are found inside buildings, often underneath an opening in the roof. Each Level VIB residential building had one hearth, a small-dished basin spatially located in a more central area of the room. Düring and Marciniak $(2006,175)$ argue that the frequency and location of these hearths tracks the spatial distribution of autonomous households.

\section{Machines for the dead: tracking the placement of the ancestors}

Within House Societies the House endures as a material and immaterial manifestation of social alliances, defined both biologically and through fictive framing, of temporal narratives that bound past, present and future House members together. Houses can serve, as Thomas (2015) argues, as intergenerational machines for the dead as well as the living. Through the selective placement of the dead at Çatalhöyük, House members reaffirmed alliances and linked people together, not just emotionally and symbolically, but physically within space and across time. Through repetitive burial practices and the interior decoration of buildings, House members linked ritual to space and place (Düring 2007a; Hodder 2014; Mellaart 1967). Burial practices were spatially focused on specific buildings (Boz \& Hager 2013; Düring 2006, 201-11; Hodder \& Pels 2010; Mellaart 1967, 205; Nakamura \& Meskell 2013, 433). Çatalhöyük people generally placed their dead underneath specific floors and platforms of certain buildings, some, but not all of which contained extensive decoration (Boz \& Hager 2013; Düring 2006; Nakamura \& Meskell 2013) (Table 2; Fig. 7). Düring (2006, 201-11) notes that community members used only 20 per cent of buildings to bury their dead, with specific rooms within clusters of buildings being defined and maintained 


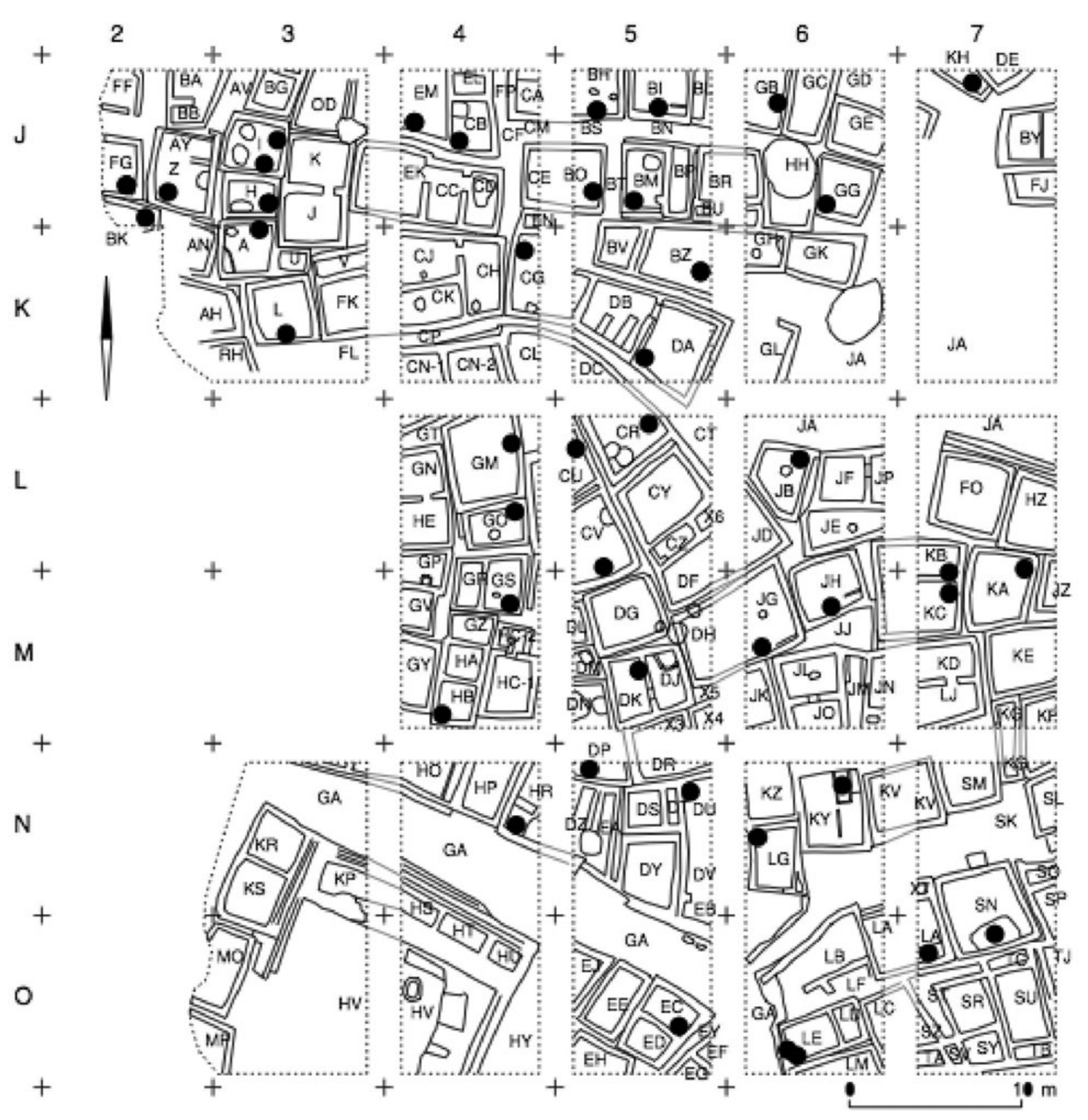

Figure 5. Distribution of fire hearths within buildings, showing alleyways and grouping of buildings that may have served as neighbourhoods, Asikli Höyük, Turkey. (From Düring \& Marciniak 2006, fig. 4.)

as the primary, but not exclusive, place of the dead (Fig. 7). While burial rooms were dispersed across the entire Level VIB area, they are spatially separated from each other. I argue that the spatial machinery of burial linked space, place, and social memories of the dead to craft, reinforce, or transform relationships of a household's inhabitants to membership in their House.

\section{Creating and decorating spaces for the living and the dead}

Çatalhöyük Level VIB House members buried their dead in select rooms and created symbolic spaces through the construction of bulls' heads, horn benches and paintings (Table 2; Fig. 7). Several researchers (e.g. Czeszewska 2013; Hodder 2014; Mellaart 1967, 


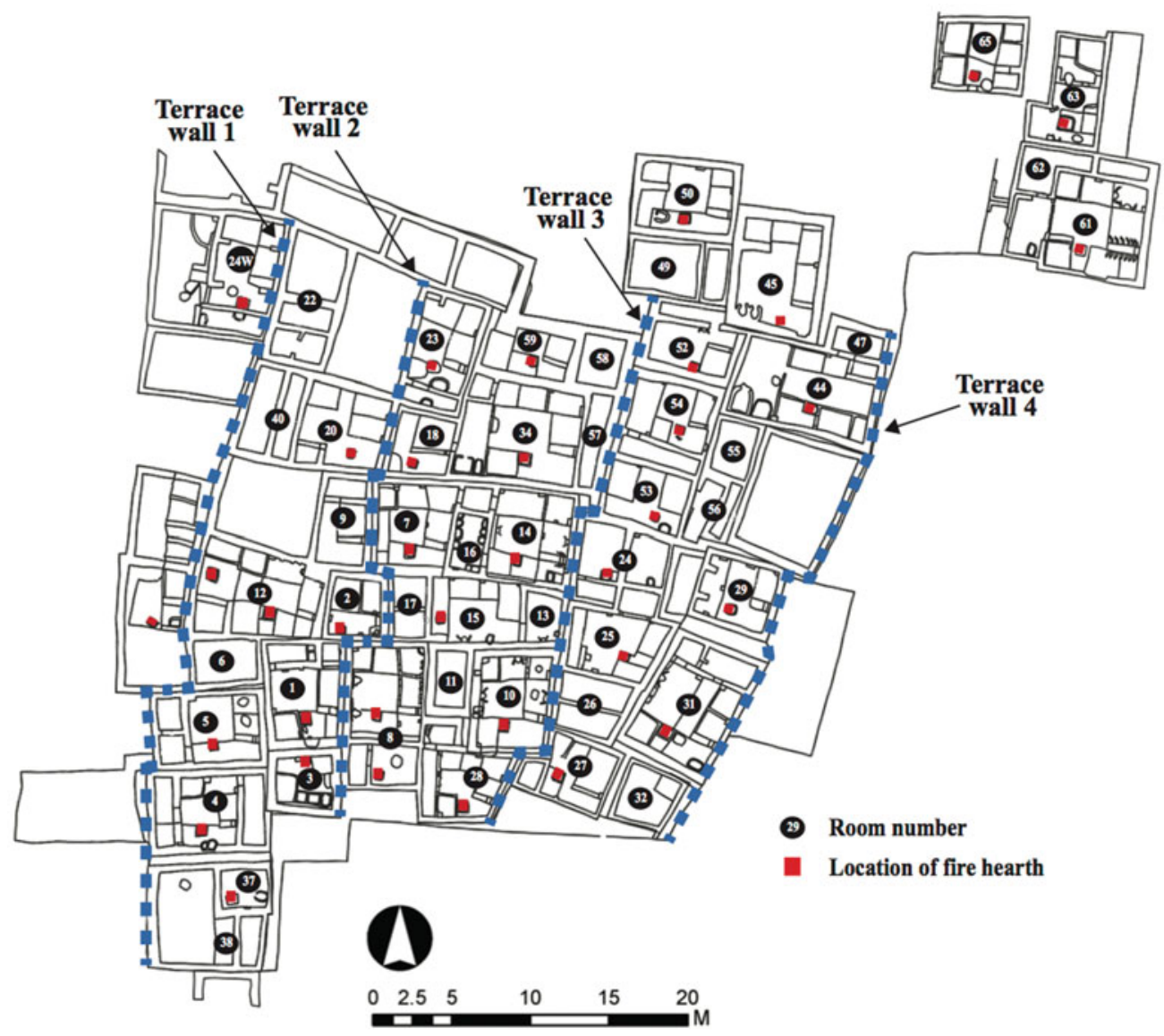

Figure 6. Location of fire hearths (red squares), individual room numbers (based on Düring 2006, figs. 6.25 \& 6.26; Mellaart 1967), and major north-south terrace walls (dashed blue line) descending in elevation from east (highest elevation) to west (lowest), Level VIB, South Area, Çatalhöyük, Turkey. (See also Table 2.)

table 16, 102-3; Nakamura \& Meskell 2013) have explored how these data may reflect different social and ritual practices at Çatalhöyük. Hodder (2014) envisions domestic architectural features, with internal decorations of painted murals and platforms and/or the construction of sculptural features on walls or floors, as a single combined category that he identifies as symbolic elaboration. This broad framing is problematic, as it conflates three significantly different phenomena: 1) functional architecture, including domestic architectural features such as platforms, basins, and hearths; 2) built display elaboration that includes horn benches, bucrania, splayed figures, and bull and ram's horn inserts, and 3) wall and platform painting. With the exception of storage rooms, functional architecture such as hearths and platforms is found in most rooms and associated with domestic life. Wall and platform paintings occur less frequently and include red or black geometric forms and, in some cases, handprints. In con- trast, built display elaboration occurs infrequently, clearly in less than 20 per cent of excavated residential rooms.

The comparative spatial distribution of burial practices and display elaboration helps us understand why people constructed display elaboration in the way they did. In general Level VIB House members buried their dead in three ways: burials in rooms with elaborate display features; burials in rooms without any elaborate decorations; and burials in both elaborated and unelaborated rooms. Level VIB House members often buried their dead in specific rooms with no built display elaboration, and in different buildings, buried their dead in rooms with extensive built display elaboration (Fig. 7, Table 3). For example, within rooms $1,7,20,29$ and 34 people buried 132 of their relatives (with an average of 26 burials per room) with no built display elaboration. Similarly, in buildings $2,3,4,5,11$, and 32 , they buried 34 household members (average 5.6 burials per room) 


\section{Material Geographies of House Societies}

Table 2. Comparison of house group, organized by rooms, for Level VIB, South Area, Çatalhöyük, listing number of burials, hearths, presence of platforms, display elaboration and storage. House group clusters are labelled by the room number with the highest number of burials. Shaded grey areas highlight rooms with highest number of burials or display elaboration. Display elaboration: horn bench (HB), bucranium (BC), splayed figures (SF), bull and ram horns $(B R H)$, leopard relief (LR). Storage: storage bin (SB), storage room (SR), connected storage room (CSR). (Based on Czeszewska 2013; Düring 2006, fig 6.25; Mellaart 1967, tables 13 \& 16.)

\begin{tabular}{|c|c|c|c|c|c|c|c|c|}
\hline $\begin{array}{l}\text { House } \\
\text { group } \\
\text { number }\end{array}$ & $\begin{array}{l}\text { Building } \\
\text { number }\end{array}$ & $\begin{array}{l}\text { Number } \\
\text { of burials }\end{array}$ & $\begin{array}{c}\text { Number } \\
\text { of } \\
\text { hearths }\end{array}$ & $\begin{array}{l}\text { Presence of } \\
\text { platforms/ } \\
\text { basins }\end{array}$ & $\begin{array}{c}\text { Built } \\
\text { display } \\
\text { elaboration }\end{array}$ & $\begin{array}{c}\text { Wall } \\
\text { paintings }\end{array}$ & Storage & Other \\
\hline \multirow{10}{*}{ HG 34} & 34 & 43 & 1 & Yes & - & - & - & \multirow{10}{*}{$\begin{array}{l}\text { Building } 34 \text { has a high frequency of } \\
\text { burials, but neither this building nor } \\
\text { any others in this house group exhibit } \\
\text { display elaboration. }\end{array}$} \\
\hline & 20 & 16 & 1 & Yes & - & - & - & \\
\hline & 18 & - & 1 & Yes & - & - & - & \\
\hline & 23 & - & 1 & Yes & - & - & - & \\
\hline & 59 & - & 1 & Yes & - & - & - & \\
\hline & $24 \mathrm{~W}$ & - & - & - & - & - & - & \\
\hline & 22 & - & - & - & - & - & SR & \\
\hline & 40 & - & - & - & - & - & SR & \\
\hline & 57 & - & - & - & - & - & SR & \\
\hline & 58 & - & - & - & - & - & SR & \\
\hline \multirow{9}{*}{ HG 7} & 7 & 29 & 1 & Yes & - & - & - & \multirow{9}{*}{$\begin{array}{l}\text { Unclear relationship with building } 35 \\
\text { and } 36 \text { to the west. Building } 7 \text { with } \\
\text { high number of burials and } 14 \text { with } \\
\text { high levels of display elaboration are } \\
\text { interconnected. Storage room } 16 \text { is } \\
\text { accessed via room } 14 .\end{array}$} \\
\hline & 2 & 5 & 1 & Yes & - & - & - & \\
\hline & 14 & 3 & 1 & Yes & $\begin{array}{c}\text { 4: HB, BC, } \\
\text { SF, BRH }\end{array}$ & - & - & \\
\hline & 15 & 1 & 1 & Yes & 1: BRH & Yes & - & \\
\hline & 12 & 1 & 2 & Yes & - & - & - & \\
\hline & 13 & - & - & Yes & 1: BRH & - & - & \\
\hline & 9 & - & - & Yes & - & - & - & \\
\hline & 16 & - & - & - & - & - & SB & \\
\hline & 17 & - & - & - & - & - & SR & \\
\hline \multirow{11}{*}{ HG 1} & 1 & 32 & 1 & Yes & - & Yes & - & \multirow{11}{*}{$\begin{array}{l}\text { Building } 1 \text { with high number of burials } \\
\text { but no display elaboration, and } \\
\text { building } 10 \text { and } 8 \text { with high frequency } \\
\text { of display elaboration and high } \\
\text { number of burials. }\end{array}$} \\
\hline & 10 & 32 & 1 & Yes & $\begin{array}{l}\text { 4: HB, BC, } \\
\text { SF, BRH }\end{array}$ & - & - & \\
\hline & 8 & 15 & 2 & Yes & $\begin{array}{c}\text { 3: BC, SF, } \\
\text { BRH }\end{array}$ & Yes & - & \\
\hline & 5 & 7 & 1 & Yes & - & - & CSR & \\
\hline & 11 & 6 & - & - & - & - & SR & \\
\hline & 4 & 5 & 1 & Yes & - & - & CSR & \\
\hline & 3 & 4 & 1 & Yes & - & - & & \\
\hline & 28 & - & 1 & Yes & - & - & SB & \\
\hline & 37 & - & 1 & - & - & - & - & \\
\hline & 6 & - & - & - & - & - & - & \\
\hline & 38 & - & - & - & - & - & SR & \\
\hline \multirow{8}{*}{ HG 29} & 29 & 12 & 1 & Yes & - & - & SR & \multirow{8}{*}{$\begin{array}{l}\text { Building } 29 \text { with high burial frequency } \\
\text { contrasts with building } 31 \text { with high } \\
\text { frequency of display elaboration and } \\
\text { one burial. }\end{array}$} \\
\hline & 32 & 7 & - & Yes & - & - & - & \\
\hline & 31 & 1 & 1 & Yes & 2: BC, SF & - & - & \\
\hline & 25 & - & 1 & Yes & - & - & - & \\
\hline & 27 & - & 1 & Yes & - & - & - & \\
\hline & 24 & - & 1 & - & - & - & - & \\
\hline & 26 & - & - & - & - & - & SR? & \\
\hline & No \# & - & - & - & - & - & SR & \\
\hline
\end{tabular}


Table 2. Continued

\begin{tabular}{|c|c|c|c|c|c|c|c|c|}
\hline $\begin{array}{c}\text { House } \\
\text { group } \\
\text { number }\end{array}$ & $\begin{array}{l}\text { Building } \\
\text { number }\end{array}$ & $\begin{array}{l}\text { Number } \\
\text { of burials }\end{array}$ & $\begin{array}{c}\text { Number } \\
\text { of } \\
\text { hearths }\end{array}$ & $\begin{array}{c}\text { Presence of } \\
\text { platforms/ } \\
\text { basins }\end{array}$ & $\begin{array}{c}\text { Built } \\
\text { display } \\
\text { elaboration }\end{array}$ & $\begin{array}{l}\text { Wall } \\
\text { paintings }\end{array}$ & Storage & Other \\
\hline \multirow{10}{*}{ HG 44} & 44 & 6 & 1 & Yes & 1: LR & Yes & & \multirow{10}{*}{$\begin{array}{l}\text { Low number of burials within the } \\
\text { house group. Leopard relief in building } \\
44 .\end{array}$} \\
\hline & 45 & - & 1 & Yes & - & - & & \\
\hline & 54 & - & 1 & Yes & - & - & & \\
\hline & 53 & - & 1 & Yes & - & - & CSR & \\
\hline & 52 & - & 1 & Yes & 1: $\mathrm{HB}$ & - & - & \\
\hline & 50 & - & 1 & Yes & 2: HB SF & Yes & - & \\
\hline & 47 & - & - & - & - & - & - & \\
\hline & 49 & - & - & - & - & - & SR & \\
\hline & 56 & - & - & - & - & - & SR & \\
\hline & 55 & - & - & - & - & - & SR & \\
\hline \multirow{4}{*}{ HG 61} & 61 & 13 & 1 & Yes & $\begin{array}{c}\text { 3: } \mathrm{BC}(\times 2), \\
\mathrm{HB}\end{array}$ & - & $?$ & \multirow{4}{*}{$\begin{array}{l}\text { Building } 61 \text { has the highest frequency } \\
\text { of burials and display elaboration. }\end{array}$} \\
\hline & 63 & - & 1 & Yes & - & - & CSR & \\
\hline & 65 & - & 1 & Yes & - & Yes & - & \\
\hline & 62 & - & - & - & - & - & SR & \\
\hline
\end{tabular}

with no built display elaboration. In contrast, in other contemporary cases (building 8, 10 and 61) household members buried 60 of their household dead (average 20 burials per room) in rooms with extensive built display elaboration. Viewed collectively it appears that different House members in Çatalhöyük Level VIB carefully maintained distinctive burial practices specific to their Houses across generations, often in rooms that were right next to each other (e.g. buildings 34 and 14 , or buildings 1 and 8 ). Further research, such as DNA analysis, will be necessary to understand if this hypothesis bears out and reflects the organization of different practices by Houses, or perhaps the burial of individuals was based more closely on House status, life course, or some other criteria.

\section{Separating spaces for the living and the ancestors}

In their multi-period village-scale analysis of Çatalhöyük, Hodder (2014, 15), Nakamura and Meskell (2013) and Mazzucato (2013) argue there is no correlation between burial frequency and elaboration. While technically correct, this binary framing overlooks a critical pattern: House members buried their dead in different types of rooms, and this reflects intentional and repeated differential practices through which meanings, memory, and identity of the living and the dead were constructed. In many cases Level VIB House members buried groups of deceased relatives (more than five burials) in rooms lacking built display elaboration, and at the same time, they buried select people in neighbouring rooms with extensive display elaboration (Table 4; Fig. 8). For exam- ple, people buried 12 individuals under the platforms in building 29, but they did not create any display elaboration in that room. In contrast, they selected neighbouring building 31 as the location to emplace a bucranium and a splayed figure, and yet also buried one individual in the room. In the case of building 34, 43 burials were interred in this unelaborated space.

Çatalhöyük Level VIB House member appear to have had clear rules for who was buried where, and these were connected to how different rooms were decorated. For example, people residing in the building that encompassed rooms $7,7 / 14,16$, and 14 buried their dead in two distinctly different places. Rooms 7 and 14 are about the same size, each with a single hearth, and with similar numbers and sizes of platforms. There is a central passage (Room 16) with two entryways between these rooms, and a centrally placed storage room with eight storage bins accessed only from room 14 (Fig. 8; see Düring \& Marciniak 2006). As with people living in other buildings, House members buried 29 people in undecorated room 7 . In contrast, House members buried only 3 individuals in connected room 14 , a room adorned with 12 highly visual elaboration features with multiple bucrania inset into the western and eastern walls and with a bench including inset horns.

The observed burial patterning illustrates the repeated selection and recognition of specific individuals, the abstraction of select community members if you will, at the point of death and with their burial. The degree of association, and in other cases lack of association, between visual elaboration and burials 


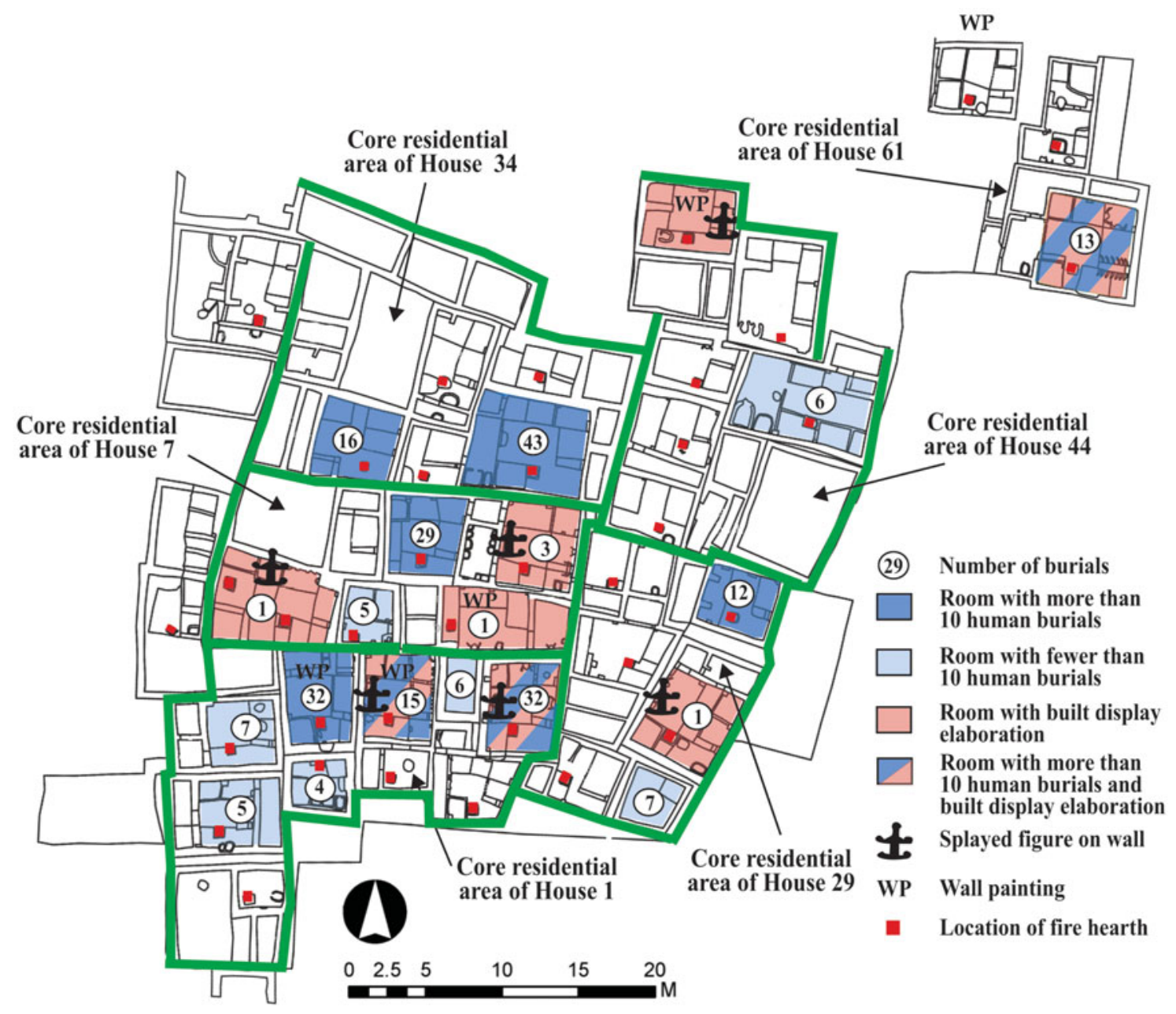

Figure 7. Spatial geography of the dead, Level VIB, South Area, Çatalhöyük Turkey. (Based on Czeszewska 2013; Düring 2006, figs. 6.25 \& 6.26; Hodder 2013; Mellart 1967.)

varies significantly from room to room, building to building (Table 2). In buildings 7, 29 and 34, House members buried their dead in rooms with no elaboration. In building 1, people buried 32 people in an undecorated room, next to neighbouring building 8 , where 15 people were buried with extensive built display elaboration. Several buildings, such as buildings 8 and 10, contain some of the highest frequencies of visual elaboration at Çatalhöyük. For example, Houses members buried 32 people in building 10, which contained a horn bench, bucranium, splayed figure, and bull and ram horns. Interestingly, recent excavations have demonstrated that building 10 was constructed on top of a sequence of buildings, with a high density of burials recovered from these buildings. At the base of this was building 17 , where at least 10 people were buried (Taylor 2016, 56), and this building was constructed on a substantial midden previously used for burials (Taylor 2017).
Clearly House members opted to bury select deceased members of their community inside visually impressive settings (Table 4; Mellaart 1967, fig. 33), and in others in unelaborated contexts, but why? In many cases, House members tended to segment their burial and decorative practices spatially, most often separating display, performance and burial areas. Other examples, however, highlight that in Level VIB there were different social practices of burial and display associated with different Houses. The variation in burial practices may reflect that singlefamily households and multi-family Houses tended to bury people according to specific traditions: individual Houses may have enacted their own specific mortuary and elaborative architectural practices that they used to anchor their membership, ancestry and futures. Alternatively, different Çatalhöyük Houses members, or perhaps sodality members (see Mills 2014), may have been afforded different 
Table 3. Frequency of rooms used for burial compared to built display elaboration, Level VIB, South Area, Çatalhöyük, Turkey. Note that at times use of areas is overlapping, with people living in these spaces, burying their dead under the floors and creating symbolic displays. (Düring 2006; Hodder 2014; Mellaart 1967.)

\begin{tabular}{|c|c|c|c|c|c|}
\hline & & & \multicolumn{3}{|c|}{ Burial frequency within settlement } \\
\hline & & & $\begin{array}{l}\text { Room with more } \\
\text { than } 10 \text { burials }\end{array}$ & $\begin{array}{l}\text { Rooms with } \\
\text { between } 9 \text { and } \\
2 \text { burials }\end{array}$ & $\begin{array}{c}\text { Rooms with less } \\
\text { than } 2 \text { burials }\end{array}$ \\
\hline & & & $8 / 52(15.4 \%)$ & $8 / 52(15.4 \%)$ & $36 / 52(69.2 \%)$ \\
\hline \multirow{3}{*}{$\begin{array}{l}\text { Frequency of } \\
\text { built display } \\
\text { elaboration } \\
\text { (bucrania, wild } \\
\text { animal parts, } \\
\text { wild animal } \\
\text { representations) }\end{array}$} & $\begin{array}{c}\text { Rooms } \\
\text { containing } \\
\text { two or more }\end{array}$ & $6 / 52(11.5 \%)$ & $\begin{array}{c}3(5.8 \%) \\
\text { (Rooms 8, 10, 61) }\end{array}$ & $\begin{array}{c}1(1.9 \%) \\
\text { (Room 14) }\end{array}$ & $\begin{array}{c}2(3.8 \%) \\
\text { (Rooms 31, 50) }\end{array}$ \\
\hline & $\begin{array}{c}\text { Rooms } \\
\text { containing } \\
\text { one }\end{array}$ & $4 / 52(7.7 \%)$ & 0 & $\begin{array}{c}1(1.9 \%) \\
\text { (Room 44) }\end{array}$ & $\begin{array}{c}3(5.8 \%) \\
\text { (Rooms 13, 15, } \\
52)\end{array}$ \\
\hline & $\begin{array}{c}\text { Rooms with } \\
\text { no } \\
\text { elaboration }\end{array}$ & $42 / 52(80.8 \%)$ & $\begin{array}{c}5(9.6 \%) \\
\text { (Rooms 1, 7, 20, } \\
29,34)\end{array}$ & $\begin{array}{c}6(11.5 \%) \\
\text { (Rooms 2, 3, } 4 \\
5,11,32)\end{array}$ & $\begin{array}{c}31(59.6 \%) \\
\text { (Rooms 6, 9, 12, } \\
16,17,18,22,23, \\
24,24 W, 26,25, \\
27,28,37,38,40, \\
45,47,49,53,54 \\
56,55,57,58,59, \\
62,63,65, \text { No\#) }\end{array}$ \\
\hline
\end{tabular}

spatially distinct burial treatments based on age, status, kinship, or perhaps some other factor, such as possessing specialized bodies of knowledge, lived experiences, or social, political or economic links in life. Further research will be required to understand the mechanisms of selection for who was buried in these different rooms, the extent to which this reflects markers of power, authority, or ancestry within a House, and how these social relationships were materialized through burial goods or organization.

Research by Carleton et al. (2013, table 2) highlights that Çatalhöyük buildings with elaboration were maintained longer, and potentially were rebuilt more frequently, than buildings focused on burial of the dead. This research demonstrates that Neolithic people did not commonly rebuild rooms where they placed many burials, opting instead to rebuild the rooms and buildings where there were significant display elaborations. Carleton et al. (2013, 1819, table 2) demonstrate that rebuilding of walls for all South levels is strongly correlated with construction of pillars (result of 0.82 from three-factor model using Varimax and Oblimin rotations) and decoration (0.45), but not benches $(-0.15)$, platforms, or the number of rooms (0.19). Given that pillars are frequently a location for the construction of bucrania and other remains set into the pillars (Hodder 2006), this lends statistical support to the argument that House members rebuilt rooms with decorative elaboration. They argue, moreover, that the original framing of History Houses (Hodder \& Pels 2010) erroneously conflates arguments for architectural longevity, high burial frequency and architectural and display elaboration. Additionally, this current study illustrates that household members were more likely to rebuild rooms/buildings with significant amounts of display elaboration as well as spatially compartmentalizing display elaboration and burial practices at Çatalhöyük South Area.

\section{Taphonomy of identity: Çatalhöyük North Area}

Excavations of Çatalhöyük North Area provide a comparative case study to understand the separation of built display elaboration, burials, and the manner in which household ancestors were buried in specific locations in South Area's Level VI. Excavations in the North Area, previously termed area 4040, have exposed numerous buildings and open areas across a broad horizontal space (Baranski et al. 2017; Farid 2014; Tung 2014; 2015; 2016). While detailed Bayesian analysis is ongoing for the North Area, stratigraphic research by Farid (2014) makes it possible to identify general building phases and make some preliminary comparison of the separation of display elaboration and how only select buildings were used for burials. Based on stratigraphic analysis and radiocarbon dating, and supported by analysis of chipped stone tools and ceramics, Farid (2014) puts forth a detailed grouping of the human occupation of buildings. Farid (2014, 96) argues that the buildings and built environment of the North Area generally overlap in date with South Area Levels VI-VII. 
Table 4. Comparison of rooms in houses 7, 7/14 16, and 14, Level VIB, South Area, Çatalhöyük (based on Düring 2007a). This table illustrates differential use of rooms with the location of burials, display elaboration (horn benches, bucranium, splayed figures, and bull's and ram's horn inserts) and functional elaboration (platforms, basins).

\begin{tabular}{|c|c|c|c|c|}
\hline & Room 7 & Room 7/14 & Room 16 & Room 14 \\
\hline Floor area & 5.3 sq. m & 0.65 sq. m & 1.5 sq. m & 5.5 sq. m \\
\hline Burials & 29 & 0 & 0 & 3 \\
\hline Hearths & 1 & 0 & 0 & 1 \\
\hline Storage features & None & None & 8 clay bins & None \\
\hline $\begin{array}{l}\text { Functional } \\
\text { elaboration }\end{array}$ & Platforms & None & None & Platforms \\
\hline Display elaboration & 0 & 0 & 0 & $\begin{array}{l}\text { 12: Bull's head }(\times 2) \text {, Ram's } \\
\text { head }(\times 3) \text {, horned bench }(3 \\
\text { sets }), \text { bucranium }(\times 3), \\
\text { splayed figure }(\times 1)\end{array}$ \\
\hline $\begin{array}{l}\text { Generalized use of } \\
\text { space }\end{array}$ & $\begin{array}{l}\text { Domestic and ritual } \\
\text { activities: Primary } \\
\text { focus as an ancestral } \\
\text { burial room }\end{array}$ & Passage way & Food storage & $\begin{array}{c}\text { Domestic and ritual } \\
\text { activities: Primary focus on } \\
\text { visual display }\end{array}$ \\
\hline
\end{tabular}

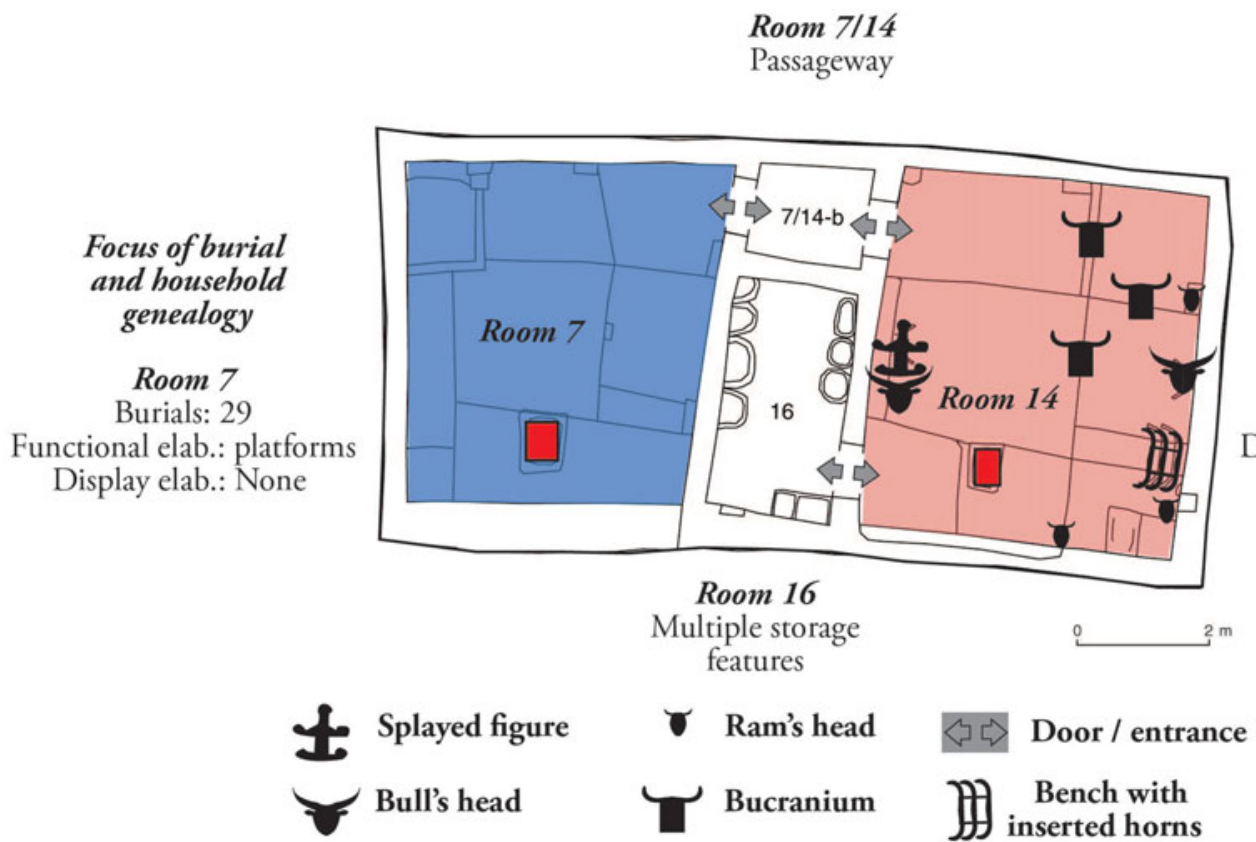

Figure 8. Display elaboration and burial concentrations, rooms 7, 7/14,14, 16, Level VIB, South Area, Çatalhöyiuk, Turkey. Rooms 7 and 14 are connected via passageway 7/14 with two doors. Room 16 is a storage room with multiple clay food-storage features. Fire hearths are noted in red, with blue denoting area of high burial frequency and absence of display elaboration and red denoting area where display elaboration was constructed. (Based on Düring \& Marciniak 2006, fig. 7; Mellaart 1967.)

Farid's (2014, fig 4.28) phasing of Level 4040 Level $\mathrm{G}$ provides a preliminary means of exploring the social geography of the North Area and the period of time some buildings were occupied. Bayliss et al. (2013) provide a Bayesian analysis of 36 radiocarbon samples that helps us understand the life his- tories of buildings 1 and 3 . They have determined that building 1 , where household members buried 60 people, was occupied for between 20 and 90 years (95 per cent probability) or 60 and 145 years (68 per cent probability). This estimate for multi-generation use is consistent with the high frequency of burials recovered 
Table 5. Comparison of burial frequency and presence of built display elaboration, North Area, Çatalhöyük. Shaded grey highlights rooms with built display elaboration. Display elaboration: horn bench (HB), bucranium (BC), and bull and ram horns (BRH). (Based on Eddisford 2011; House 2007; Tung 2013; 2014; 2015; 2016).

\begin{tabular}{|c|c|c|c|c|c|c|}
\hline $\begin{array}{c}\text { Building } \\
\text { no. }\end{array}$ & $\begin{array}{l}\text { No. of } \\
\text { burials }\end{array}$ & $\begin{array}{c}\text { No. of } \\
\text { hearths }\end{array}$ & $\begin{array}{c}\text { Presence of } \\
\text { platforms/ } \\
\text { basins }\end{array}$ & $\begin{array}{l}\text { Built display } \\
\text { elaboration }\end{array}$ & $\begin{array}{c}\text { Wall } \\
\text { paintings }\end{array}$ & $\begin{array}{c}\text { Phasing } \\
\text { (Farid 2014) }\end{array}$ \\
\hline 1 & 60 & 1 & Yes & - & Yes & G \\
\hline 3 & 5 & 1 & Yes & - & - & G \\
\hline 48 & 1 & 1 & Yes & - & - & G \\
\hline 49 & 15 & 1 & Yes & - & Yes & G \\
\hline 52 & 14 & 1 & Yes & 3: HB, BC, BRH & - & G \\
\hline 58 & $? ?$ & 1 & Yes & - & - & G \\
\hline 59 & 1 & 1 & Yes & 1: BC & Yes & G \\
\hline 77 & 31 & 1 & Yes & - & Yes & G \\
\hline 108 & 10 & 1 & Yes & - & - & G \\
\hline 114 & 3 & 1 & Yes & - & - & G \\
\hline 119 & 0 & 1 & Yes & - & Yes & $\begin{array}{c}\mathrm{F} . \\
\text { Incomplete } \\
\text { excavation } \\
\text { (Tung 2016) }\end{array}$ \\
\hline 131 & 18 & 1 & Yes & - & - & $\begin{array}{c}\mathrm{F} . \\
\text { Incomplete } \\
\text { excavation } \\
\text { (Tung 2016) }\end{array}$ \\
\hline
\end{tabular}

in this building. It is not clear, however, to what extent this temporal use life is representative of other buildings.

Level G mortuary data support the argument that community members buried many of their dead in select rooms (Table 5; Fig. 9). Examination of the North Area distribution of buildings, burial locations and buildings/rooms with built display elaboration, demonstrates that House members buried a disproportionate number of dead in select buildings, with the greatest concentrations in building 1 (60 people) and 77 (31 people), with around 15 people in buildings 49 and 52. ${ }^{1}$ Other buildings, such as 48 and 59, had only one burial, and it is possible that these were from later building uses. Villagers buried their dead in about 50 per cent of the buildings in the North Area. Echoing what is seen in the South Area, however, villagers placed groups of the dead in only 25 per cent of the buildings. While noting the common pattern between these North and South Areas, it is important to note that, with on-going analysis, these results should be viewed as preliminary.

Excavation results from the North Area also support the argument that, at times, House members constructed display elaboration and buried their dead in different spatial locations (Table 5). As outlined by Bogaard (2009, fig. 3), Building 52 had storage spaces, with a built-in bucranium and horned bench. The building also was used for the burial of 14 individuals placed underneath the platforms. In contrast to Building 52, Building 1 has 60 burials and a single cattle horn set into the central wall. Remains of a dismantled bucranium were found in this building. It is possible, however, that this was not an elaboration feature contemporary with the burials. While demonstrating variability, the general overall pattern of the North Area is similar to that seen in the South Area.

The detailed excavation of Çatalhöyük North Area demonstrates that, while fire hearths and ovens were often rebuilt, and at times spatially shifted within and between individual rooms, the overall pattern is that only one of each of these was uncovered in individual rooms/buildings. Questions exist, of course, as to how representative the last occupation of North Area is of the rest of the settlement within this period, and to what extent Çatalhöyük Level VIB is representative of broader settlement at different points of time. Broader comparative research will have to await publication of more detailed architectural floor plans.

\section{Houses longevity}

Research at numerous Neolithic sites highlights that groups of buildings were often initially constructed on pre-existing midden deposits, were rebuilt in the 


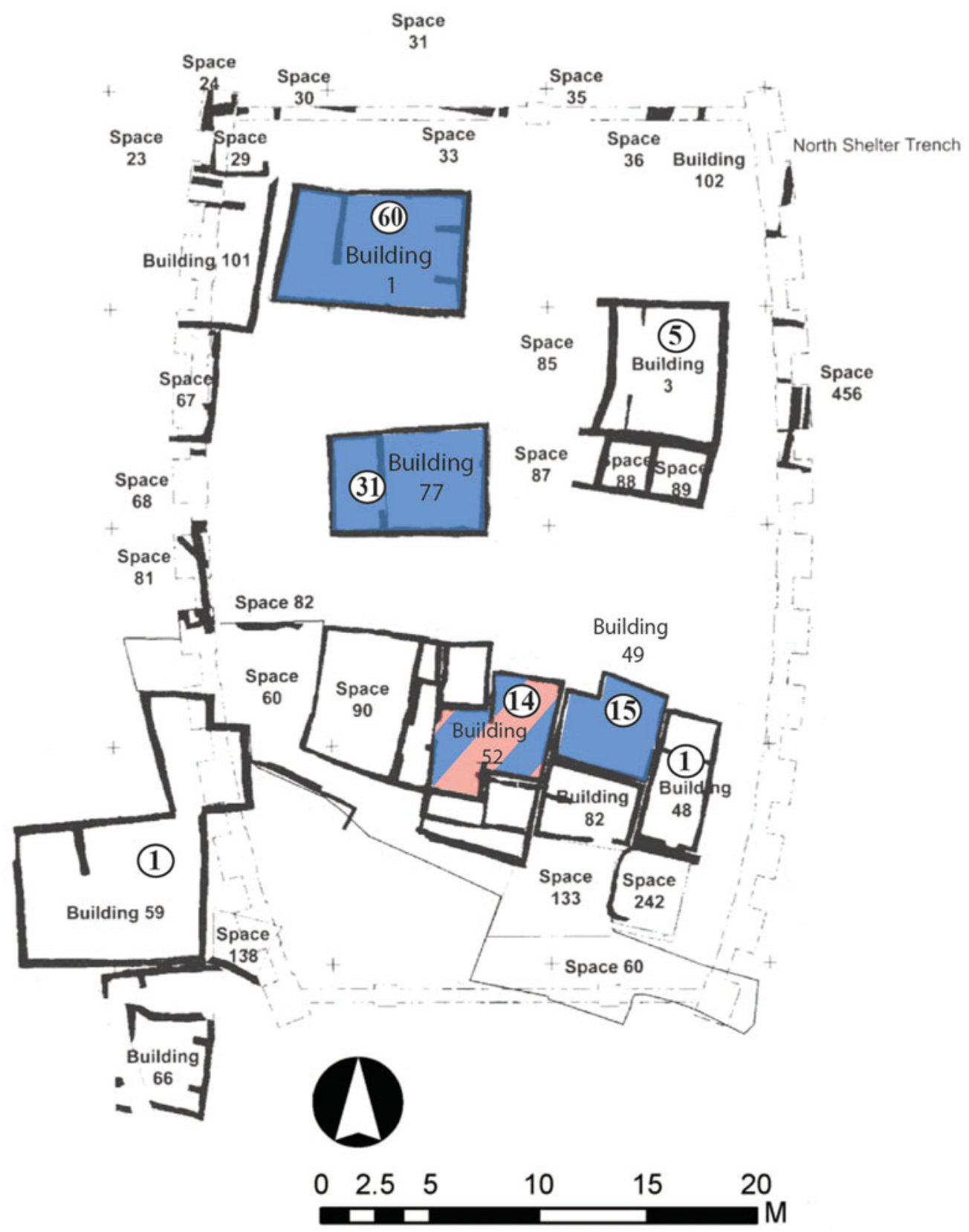

Figure 9. Spatial geography of the dead, North Area, Çatalhöyïk, Turkey. Burial location and frequency illustrated with a circle indicating the number of burials and built display elaboration (pink shaded areas). Rooms with a high frequency of burials, defined as more than 10 burials, are surrounded by dark blue (see Table 4). (Based on Farid 2014; Tung 2013; 2014; 2015; 2016.)

same location several times, and were eventually abandoned. Framing Neolithic social organization as House Societies may provide a partial answer as to why individual groups of buildings were abandoned. Specifically, if one accepts the broader arguments that Anatolian Neolithic villages were organized along the lines of something similar to House Societies, then it is possible that the observed abandonment of some architectural sequences was linked to the closing of specific Houses. As noted by McKinnon (2000), membership within contemporary House Societies is often fluid, and household members actively recruit people to secure labour for household tasks, fieldwork and protection from other households. As with sodalities, membership in Houses would have been based on practices, the use of material goods and a range of tan- 
gible and intangible dimensions. This is important, for the collapse of Houses and abandonment of buildings was potentially linked to broad diachronic processes such as regional environmental change and population decreases, or alternatively, as pointed out by McKinnon, small-scale synchronic processes such as shifting House membership, competition over property and seasonal control of labour. The abandonment of buildings might also have been linked to people leaving one House and becoming new members of a different multi-family household through marriage, adoption, or fostering. Similarly, individual singlefamily or multi-family households may have moved to a different area within the home village, or multifamily household members left to live in another regional village.

It is possible that the abandonment of specific Çatalhöyük buildings, or buildings sequences such as House 65, 56, 44 (Farid 2014), was linked to the collapse of a House. There are, moreover, multiple cases in the South Area of buildings, and in some cases groups of buildings, being constructed on top of areas that were used as midden for 100 years or more, the buildings being used for a period of time before being abandoned. One possible explanation for the abandonment of structures is that they reflect the demise of specific Çatalhöyük lineage groups with larger, and potentially more powerful, multi-family households absorbing smaller single- and multi-family households.

\section{Discussion}

This paper explores the Neolithic village through the interpretive lens of House Societies and co-existing Houses, and considers the material footprint of multifamily Houses. This interpretive framing, as noted by Baird et al. $(2016,4)$, has not generated conversation among researchers. As seen with the study of Neolithic Aşikli Höyük (Düring \& Marciniak 2006; Özbaşaran 1998; 2011), Tell Halula (Kuijt et al. 2011; Molist 1998; 2001), Çatalhöyük (Bogaard et al. 2009; Conolly 1999; Düring 2007a) and Sha'ar Hagolan (Garfinkel 2006), researchers are exploring the question of how Neolithic communities were built around the social and economic unit of the single-family household, but with only limited consideration of potential suprahousehold groups. Drawing upon a range of data, I suggest that at its core social relations within central Anatolian Neolithic villages in general, and the settlement of Çatalhöyük in specific, was framed around multiple competing and cooperating Houses, similar to House Societies (Lévi-Strauss 1979). House members resided in clusters of abutting mud buildings, all largely the same size and with similar internal organization, with social relations and membership framed around two distinct conceptual, and at times physically separated, spaces: spaces in which the ancestors were buried beneath the floor and spaces constructed with symbolic display elaboration. These spaces were rare with less than 20 per cent, and more likely 10 per cent, of all rooms being used for these purposes (Table 3). House members used select rooms repeatedly, at times through multiple generations, with the dead being placed in pre-designated locations during the life history of the building.

Rooms used for burial as well as symbolic display elaboration were deeply connected to telling the generative narratives of the House as a historical and genealogical social unit, including the lives and actions of the ancestors, and in many cases embedding the ancestors physically within the fabric of the building. I suggest that, similar to what is seen with House Societies, rooms/buildings used for symbolic built display elaboration would have served as ancestral lineage buildings. While similar in size to other buildings/rooms, these lineage rooms appear to have been maintained for longer periods of time, perhaps as much as 100 or more years. The other rooms were rebuilt more frequently, perhaps every $20-30$ years, depending upon conditions.

This exploration of Çatalhöyük South Area Level VIB advances our understanding of Neolithic social organization in several ways. First, this study focuses attention on social units beyond the single-family household, to consider some of the potential social, biological and economic interconnections between multiple single-family households. This study challenges researchers to reframe our discussions and consider the interconnectivity of multiple social units, such as sodalities as argued by Mills (2014), and how the multi-family House may have existed as an organizational unit within Neolithic villages. Second, this study considers the loci of built symbolic elaboration and burial practices, thinking about ritual and social life, the construction of social memory and membership within community, and directs attention to how social networks were organized, framed and maintained by members of individual Houses. Çatalhöyük burial practices were focused on the inner areas of select buildings. The dead buried in these buildings were part of a larger multi-family House, having resided in nearby buildings, but with death were placed beneath the floor of a building focused on ancestry. Additional research will be required to understand how the coexistence of multiple competing Houses may have contributed to variation 
and commonalities in ritual practices, the material footprint of mortuary practices and construction of symbolic spaces, and the emerging social differentiation within Houses and the broader community. Third, this study advances discussion of the potential methods by which researches can identify and disentangle the material footprint of Neolithic singlefamily households and multi-family Houses at the scale of individual buildings, groups of buildings and neighbourhoods. At the moment we have working models of how single-family household members lived in small buildings, inhabited spaces only large enough for a single family, but only a poor understanding of how single families were socially and economically embedded within larger multi-family Houses, let alone neighbourhoods within villages. This current discussion and analysis of Neolithic materials data illustrates the need to consider further the intertwined networks of social relations and networks at different scales.

This study also expands discussion of prehistoric House Societies in several key ways. First, echoing other research (Borić 2007; Kahn 2014; Robin 2003), I argue that researchers need intellectually to decouple the social unit of the House from a single building, and to reframe the House with greater flexibility, so as practically to trace it across multiple residential building. Second, I argue that buildings are locations of a range of social actions, but that as researchers we are poor at identifying and discussing life within these spaces. In some House Societies buildings were used for a range of functions, including as dwelling locations, origin places and meeting houses. This paper provides preliminary insight into how members of Neolithic House Societies appear to have used different buildings, rooms and/or spaces, in different ways. Third, I argue that among House Societies where people resided in a complex of buildings, House members invested greater symbolism in select rooms/houses, and some cases, these were actively maintained as a means of perpetuating the House. While difficult to demonstrate through material data, the maintenance of individual rooms/buildings may have been envisioned as a perpetuation of life-force and as an origin place. The House can serve as a powerful vehicle for the transmission of memory from individual experiences to collective oral history, and for the crafting of intergenerational alliances linking predecessors, contemporaries and successors. Fourth, while House Societies are often viewed by researchers through the material lens of the built environment, this study contributes to a growing awareness of how House members viewed death and treatment of their ancestors as an important means of furthering inter- generational connections, developing more tangible and visual linkages to a collective past, and perpetuating identity and House membership through multiple generations.

Reflecting upon the house and household many years ago, Lee Horne $(1982,685)$ argued that houses and homes go together, but 'The question is really whether there is more to the house than meets the eye'. As demonstrated by subsequent research on households, homes and House Societies (Beck 2007; Borić 2007; Carsten \& Hugh-Jones 1995; Chesson 2003; Hendon 2010; Joyce \& Gillespie 2000; Kahn 2014; Robin 2003; Thomas 2015), there is much more to the house than meets the eye. In many ways homes and Houses are intertwined and inseparable places of human action: they are spaces and social units in which contemporary social relationships are defined and memories of the past are created. While recognizing the blurriness and flexibility of these concepts, there is value in trying to pull apart these concepts, to think about the linkages between human scale and spatial organization, and to consider their material footprint. Surprisingly, research on the Neolithic single-family household, the multi-family House and the neighbourhood is still in its infancy. This paper puts forth an interpretation of Neolithic social organization and nested networks of social relations that advances discussion and debate, and can be employed to model and test arguments for Neolithic House organization. Further research will be needed to understand to what extent Neolithic communities and social networks were organized around House Societies, sodalities, or some other suprahousehold organization. The challenge in all of this is, of course, that Neolithic social networks and organization might have been distinctly different from contemporary case studies documented by ethnographers. As such, it may be wise for researchers to frame Neolithic early agricultural villages, characterized by high residential density, emerging competing and cooperating Houses, with limited social, political and economic differentiation, as being House Society-ish-an unfolding of human relations and networks that are different from the ethnographic analogues of the present, yet grew out of the new interface of emerging food production, the need to harness labour and the human desire to develop and maintain social communities.

\section{Acknowledgements}

The idea for this paper emerged from discussions with the Çatalhöyük Templeton Foundation research team 2009-12. I am thankful to Ian Hodder, who served as a host, discussion leader, and tour guide while visiting Çatalhöyük, as 
well as all of the other Templeton project members. Comments by B. Mills, I. Hodder, A. Bogaard, K. Twiss, J. Robb, A. McMahon, N. Ames, L. Couey, N. Russell, A. Prentiss, C. Quinn, and K. Sassaman, and several anonymous readers, have greatly improved the focus and thrust of this paper. While not agreeing with some of the concepts and interpretations presented, their constructive criticism and advice have immeasurably improved the clarity and organization of this work. I am particularly thankful to A. Marciniak and $\mathrm{M}$. Chesson who pushed me to think further about the nature of the single-family Neolithic household, and the House, while commenting on multiple versions of this paper. This research has been funded by Templeton Foundation and the University of Notre Dame.

\section{Notes}

1. Field excavations in the summers of 2016 and 2017 (Baranski et al. 2017) have significantly advanced our understanding of building construction and architectural continuity. While demonstrating architectural continuity, as well as continued use of select buildings for burials, the limited horizontal excavation around these buildings makes it difficult to reconstruct an overall pre-level $\mathrm{G}$ floor plan for this area.

$$
\begin{array}{r}
\text { Ian Kuijt } \\
\text { Department of Anthropology } \\
\text { University of Notre Dame } \\
\text { Notre Dame, IN } 46556 \\
\text { USA } \\
\text { Email: ian.kuijt.1@nd.edu }
\end{array}
$$

\section{References}

Allison, P.M., 1999. Introduction, in The Archaeology of Household Activities, ed. P. Allison. London: Routledge, 1-17.

Anderson, D.G., 2013. Home, hearth and household in the circumpolar north, in About the Hearth: Perspectives on the home, hearth and household in the circumpolar north, eds. D.G. Anderson, R.P. Vishart \& V. Vaté. New York/Oxford: Berghahn Books, 262-82.

Ames, K.M., D.F. Raetz, S. Hamilton \& C. McAfee., 1992. Household archaeology of a southern Northwestern Coast plank house. Journal of Field Archaeology 19(3), 275-90.

Atalay, S. \& C.A. Hastorf, 2006. Food, meals, and daily activities: food habitus at Neolithic Çatalhöyük. American Antiquity 71, 283-319.

Aurenche, O., P. Galet, E. Régagnon-Carolin \& J. Évin, 2001. Proto-Neolithic and Neolithic cultures in the Middle East - the birth of agriculture, livestock raising, and ceramics: a calibrated ${ }^{14} \mathrm{C}$ chronology $12,500-5,500 \mathrm{cal}$ BC. Radiocarbon 43(3), 1191-1202.

Baird, D., A. Fairbairn \& L. Martin, 2016. The animate house, the institutionalization of the household in Neolithic Central Anatolia. World Archaeology 49(5), 1-24.
Banning, E.B., 2003. Housing Neolithic farmers. Near Eastern Archaeology 66(1/2), 4-21.

Baranski, M., C. Belmonte, J. Issavi, A. Kilmovicz \& J. Tripkovic, 2017. Excavations in the North Area, in Çatalhöyük 2017 Archive Report, ed. S.D. Haddow, 17-62. http://www.catalhoyuk.com/downloads / Archive_Report_2017.pdf

Bayliss, A., S. Farid \& T. Higham, 2013. Time will tell: practicing Bayesian chronological modelling on the East Mound, in Çatalhöyük Excavations. The 20002008 seasons, ed. I. Hodder. (Çatalhöyük Research Project 7/British Institute for Archaeology at Ankara 46/Monumenta Archaeologica 29.) Los Angeles (CA): Cotsen Institute for Archaeology, 53-89.

Bayliss, A., G. Brock, S. Farid, I. Hodder, J. Southon \& R.E. Taylor, 2015. Getting to the bottom of it all: a Bayesian approach to dating the start of Çatalhöyük. Journal of World Prehistory 28(1), 1-26.

Beck, R.A. Jr (ed.), 2007. The Durable House: House society models in archaeology. (Center for Archaeological Investigations Occasional Paper 35.) Carbondale (IL): Southern Illinois University.

Bickle, P., B. Chan, L. Czerniak, J. Pyzel \& C. Tsoraki, 2016. At home in the Neolithic: understanding diversity in Neolithic houses and households. Open Archaeology 2, 410-16.

Blanton, R.E., 1994. Houses and Households. A comparative study. New York (NY): Plenum Press.

Bloch, M., 2010. Is there religion at Çatalhöyük ... or just houses? in Religion in the Emergence of Civilization: Çatalhöyük as a case study, ed. I. Hodder. Cambridge: Cambridge University Press, 146-62.

Blunt, A., 2005. Cultural geography: cultural geographies of home. Progress in Human Geography 29(4), 505-15.

Bogaard, A., M. Charles, K.C. Twiss, et al., 2009. Private pantries and celebrated surplus: storing and sharing food at Neolithic Çatalhöyük, Central Anatolia. Antiquity 83, 649-68.

Boivin, N., 2000. Life rhythms and floor sequences: excavating time in rural Rajasthan and Neolithic Çatalhöyük. World Archaeology 31, 367-88.

Borić, D., 2007. The house between grand narratives and microhistory: a house society in the Balkans, in The Durable House: House society models in archaeology, ed. R.A. Beck Jr. (Center for Archaeological Investigations, Occasional paper 35.) Carbondale (IL): Southern Illinois University, 97-129.

Borić, D., 2008. First households and 'House societies' in European prehistory, in Prehistoric Europe: Theory and practice, ed. A. Jones. Chichester: Wiley-Blackwell, 109-42.

Boz, B. \& L.D. Hager, 2013. Living above the dead: intramural burial practices at Çatalhöyük, in Humans and Landscapes of Çatalhöyïk: Reports from the 2000-2008 seasons, ed. I. Hodder. Los Angeles (CA): Cotsen Institute for Archaeology, 413-40.

Brami, M.N., 2017. The Diffusion of Neolithic Practices from Anatolia to Europe: A contextual study of residential 
construction 8,500-5,500 BC cal. (BAR International series S2838.) Oxford: Archaeopress.

Buchli, V., 2010. Households and 'home cultures', in The Oxford Handbook of Material Culture Studies, eds. D. Hicks \& M.C. Beaudry. Oxford: Oxford University Press, 502-17.

Byrd, B.F., 1994. Public and private, domestic and corporate: the emergence of the Southwest Asian village. American Antiquity 59(4), 639-66.

Carleton, W.C., J. Conolly \& M. Collard, 2013. Corporate kin-groups, social memory, and 'history houses'? A quantitative test of recent reconstructions of social organization and building function at Çatalhöyük during the PPNB. Journal of Archaeological Science 40(4), $1816-22$.

Carsten, J., 1995. Houses in Langkawi: stable structures or mobile homes, in About the House: Lévi-Strauss and beyond, eds. J. Carsten \& S. Hugh-Jones. Cambridge: Cambridge University Press, 105-28.

Carsten, J. \& S. Hugh-Jones (eds.), 1995. About the House: Lévi-Strauss and beyond. Cambridge: Cambridge University Press.

Cessford, C., 2001. A new dating sequence for Çatalhöyük. Antiquity 75, 717-25.

Cessford, C., 2005. Estimating the Neolithic population of Çatalhöyük, in Inhabiting Çatalhöyük: Reports from the 1995-1999 seasons, ed. I. Hodder. Cambridge: McDonald Institute for Archaeological Research/British Institute for Archaeological Research/British Institute of Archaeology at Ankara, 325-8.

Chesson, M.S., 2003. Households, houses, neighborhoods, and corporate villages: modeling the early bronze age as a house society. Journal of Mediterranean Archaeology $16,79-102$.

Conolly, J., 1999. Technical strategies and technical change at Neolithic Çatalhöyük. Antiquity 73, 791-800.

Czeszewska, A., 2013. Wall paintings at Çatalhöyük, in Substantive Technologies at Çatalhöyük: Reports from the 2000-08 seasons, ed. I. Hodder. Los Angeles (CA): Cotsen Institute, 183-94.

Davey, P., 2007. Hearth and home, in The Architect, the Cook and Good Taste, eds. P.H. Hodgson \& R. Toyka. Basel: Birkhäuser, 100-109.

Düring, B.S., 2001. Social dimensions in the architecture of Neolithic Çatalhöyük. Anatolian Studies 51, 1-18.

Düring, B.S., 2006. Constructing Communities. Clustered Neighbourhood Settlements of the Central Anatolian Neolithic, ca. 8500-5500 cal BC. PhD thesis, Nederlands Instituut voor het Nabije Oosten.

Düring, B., 2007a. Reconsidering the Çatalhöyük community: from households to settlement systems. Journal of Mediterranean Archaeology 20(2), 155-82.

Düring, B., 2007b. The articulation of houses at Neolithic Çatalhöyük, Turkey, in The Durable House: House society models in archaeology, ed. R. Beck Jr. (Center for Archaeological Investigations Occasional Paper 35.) Carbondale (IL): Southern Illinois University, 130-53.
Düring, B. \& A. Marciniak, 2006. Households and communities in the central Anatolian Neolithic. Archaeological Dialogues 12(2),165-87.

Eddisford, D., 2011. Building 77, in Çatalhöyük 2011 Archive Report, ed. S. Farid, 32-8. http://www.catalhoyuk. com/downloads/Archive_Report_2011.pdf

Ellickson, R.C., 2008. The Household: Informal order around the fearth. Princeton (NJ): Princeton University Press.

Fairbairn, A., D. Martinoli, A. Butler \& G. Hilman, 2007. Wild plant seed storage at Neolithic Çatalhöyük East, Turkey. Vegetative Historical Archaeobotany 16, 467-79.

Farid, S., 2014. Timelines: phasing Neolithic Çatalhöyük, in Humans and Landscapes. Çatalhöyük: Reports from the 2000-2008 seasons, ed. I. Hodder. (Çatalhöyük Research Project 8/British Institute for Archaeology at Ankara Monograph 47/Monumenta Archaeologica 30.) Los Angeles (CA): Cotsen Institute of Archaeology Press, 91-129.

Flannery, K.V., 1972. The origins of the village as a settlement type in Mesoamerica and the Near East: a comparative study, in Man, Settlement and Urbanism, eds. R. Tringham, P.J. Ucko \& G.W. Dimbleby. London: Duckworth, 23-53.

Flannery, K.V., 2002. The origins of the village revisited: from nuclear to multi-family households. American Antiquity 67(2), 417-33.

Garfinkel, Y., 2006. The social organization at Neolithic Sha' ar Hagolan: the nuclear family, the extended family and the community, in Domesticating Space: Construction, community, and cosmology in the Late Prehistoric Near East, eds. E.B. Banning \& M. Chazan. (Studies in Early Near Eastern Production, Subsistence, and Environment 6.) Berlin: Ex oriente, 103-11.

Gillespie, S.D., 2007. When is a House? in The Durable House: House society models in archaeology, ed. R.A. Beck Jr. (Center for Archaeological Investigations Occasional Paper 35.) Carbondale (IL): Southern Illinois University, 25-50.

Göktük, E.H., D.J. Hillegonds, M.E. Lipschutz \& I. Hodder, 2002. Accelerator mass spectrometry dating at Çatalhöyük. Radiochimica Acta 90, 407-10.

Greenbaum, S.D. \& P.E. Greenbaum, 2002. The ecology of social networks in four urban neighborhoods. Social Networks 7, 47-76.

Hendon, J.A., 2004. Living and working at home: the social archaeology of household production and social relations, in A Companion to Social Archaeology. eds. R.W. Preucel \& L. Meskell. Oxford: Blackwell, 272-86.

Hendon, J.A., 2010. Houses in a Landscape: Memory and everyday life in Mesoamerica. Durham (NC): Duke University Press.

Hillson, S.W., C.S. Larsen, B. Boz, M.A. Pilloud, J.W. Sadvari, \& S.C. Agarwal, 2013. The human remains I: interpreting community structure, health and diet in Neolithic Çatalhöyük, in Humans and Landscapes of Çatalhöyük: Reports from 2000-2008 seasons., ed. I. Hodder. (Çatalhöyük Research Project Volume 8/British Institute for 
Archaeology at Ankara Monograph 47/Monumenta Archaeologica 30.) Los Angeles CA): Cotsen Institute of Archaeology Press, 339-96.

Hipp, J.R., B. Faris \& R.W. Boessen, 2012. Measuring 'neighborhood': constructing network neighborhoods. Social Networks 34(1), 128-40.

Hodder, I., 2006. The Leopard's Tale. Revealing the mysteries of Çatalhöyük. London: Thames \& Hudson.

Hodder, I., 2012. Entangled: An archaeology of the relationship between humans and things. Chichester: John Wiley \& Sons.

Hodder, I., 2013. The social geography of Çatalhöyük, in Integrating Çatalhöyïk: Themes from the 2000-2008 Seasons, ed. I. Hodder. Los Angeles (CA): Cotsen Institute of Archaeology, 149-67.

Hodder, I., 2014. The vitalities of Çatalhöyük, in Religion at Work in a Neolithic Society: Vital matters, ed. I. Hodder. Los Angeles (CA): Cotsen Institute of Archaeology, 133.

Hodder, I. \& C. Cessford, 2004. Daily practice and social memory at Çatalhöyük. American Antiquity 69, 1740.

Hodder, I. \& P. Pels, 2010. History houses: a new interpretation of architectural elaboration at Çatalhöyük, in Religion in the Emergence of Civilization: Çatalhöyük as a case study, ed. I. Hodder. Cambridge: Cambridge University Press, 163-86.

Hoffman, B.W., 1999. Agayadan village: household archaeology on Unimak Island, Alaska. Journal of Field Archaeology 26(2), 147-61.

Horne, L., 1982. The household in space: dispersed holdings in an Iranian village. American Behavioral Scientist 25, 677-85.

House, M., 2007. Building 59, in Çatalhöyük 2007 Archive Report, ed. S. Farid, 80-97. http://www.catalhoyuk. com/downloads/Archive_Report_2007.pdf

Janowski, M., 1995. The hearth-group, the conjugal couple and the symbolism of the rich meal among the Kelabit of Sarawak, in About the House: Lévi-Strauss and beyond, eds. J. Carsten \& S. Hugh-Jones. Cambridge: Cambridge University Press, 84-104.

Joyce, R.A. \& S.D. Gillespie (eds.), 2000. Beyond Kinship: Social and material reproduction in house societies. Philadelphia (PA): University of Pennsylvania Press.

Kahn, J.G., 2014. Household archaeology and 'house societies' in the Hawaiian archipelago. Journal of Pacific Archaeology 5(2), 18-29.

Kramer, C., 1982. Village Ethnoarchaeology: Rural Iran in archaeological perspective. New York (NY): Academic Press.

Kuijt, I., 2000. People and space in early agricultural villages: exploring daily lives, community size and architecture in the Late Pre-Pottery Neolithic. Journal of Anthropological Archaeology 19, 75-102.

Kuijt, I. \& N. Goring-Morris, 2002. Foraging, farming, and social complexity in the Pre-Pottery Neolithic of the southern Levant: a review and synthesis. Journal of World Prehistory 16(4), 361-440.
Kuijt, I., E. Guerrero Vila, M. Molist \& J. Anfruns, 2011. The changing Neolithic household: household autonomy, integration and mortuary practices, Tell Halula, Syria. Journal of Anthropological Archaeology 30(4), 502 22.

Larson, C.S., S.W. Hillson, B. Boz, et al., 2015. Bioarchaeology of Neolithic Çatalhöyük: lives and lifesyles of an early farming society in transition. Journal of World Prehistory $28,27-68$.

Lévi-Strauss, C., 1979. Nobles sauvages, in Culture, science et développement: contribution à une histoire de l'homme. Mélanges en l'honneur de Charles Morazé, ed. R. Aron. Toulouse: Edouard Privat, 41-55.

Marciniak, A., 2008. Communities, households and animals. Convergent development in Central Anatolian and Central European Neolithic. Documenta Praehistorica 35, 93-109.

Marciniak, A., M.Z. Baranski, A. Bayliss, L. Czemiak, T. Goslar, J. Southon \& R.E. Taylor, 2015. Fragmenting times: interpreting a Bayesian chronology for the Late Neolithic occupation of Çatalhöyük East, Turkey. Antiquity 89, 154-76.

Martin, D.G., 2003. Enacting neighborhood. Urban Geography 24(5), 361-85.

Matthews, W., 2012. Household life-histories and boundaries, in Last House on the Hill: BACH Area Reports from Çatalhöyük, 1997-2003, eds. R. Tringham \& M. Stevanovic. (Monumenta Archaeologica 27).) Los Angeles (CA): Cotsen Institute of Archaeology Press/British Institute at Ankara, 205-24.

Matthews, W., 2016. Humans and fire: changing relations in early agricutural and built environments in Zagros, Iran, Iraq. The Anthropocene Review 3(2), 10739.

Mazzucato, C., 2013. Sampling and mapping Çatalhöyük, in Humans and Landscape at Çatalhöyiuk: reports from the 2000-2008 seasons, ed. I. Hodder. Los Angeles (CA): Cotsen Institute.

McKinnon, S., 2000. The Tanimbarese Tavu: the ideology of growth and the material configurations of houses and hierarchy in an Indonesian society, in Beyond Kinship: Social and material reproduction in house societies, eds. R.A. Joyce \& S.D. Gillespie. Philadelphia (PA): University of Pennsylvania Press, 161-76.

Mellaart, J., 1967. Çatal Höyük: A Neolithic town in Anatolia. London: Thames \& Hudson.

Mills, B., 2014. Relational networks and religious sodalities at Çatalhöyük, in Religion at Work in a Neolithic Society: Vital matters, ed. I. Hodder. Los Angeles (CA): Cotsen Institute, 159-86.

Molist, M., 1998. Espace collectif et espace domestique dans le néolithique des Xème et VIIIème millénaires B.P. au nord de la Syrie: apports du site de Tell Halula (Vallée de l'Euphrate), in Espace naturel, espace habité en Syrie du Nord (10e-2e millénaires a.v. J-C.), eds. M. Fortin $\&$ O. Aurenche. Quebec/Lyon: Canadian Society for Mesopotamian Studies/Maison de 1'Orient méditerranéen, 115-30. 
Molist, M., 2001. Halula, village néolithique en Syrie du Nord, in Communautés villageoises du Proche Orient à l'Atlantique (8000-2000 avant notre ère), ed. J. Guilaine. Paris: Errance, 35-52.

Nakamura, C. \& L. Meskell, 2013. Burial associations, in Humans and Landscape at Çatalhöyük: Reports from the 2000-2008 seasons, ed. I. Hodder. Los Angeles (CA): Cotsen Institute.

Özbaşaran, M., 1998. The heart of a house: the hearth - Aşikli Höyük, a Pre-pottery Neolithic site in central Anatolia, in Light on Top of the Black Hill, eds. G. Arsebük, M.J. Mellink \& W. Schirmer. İstanbul: Ege Yayınları, 555-66.

Özbaşaran, M., 2011. Re-starting at Aşikli Höyük. Anatolia Antiqua 19, 27-37.

Pels, P., 2010. Temporalities of 'religion' at Çatalhöyük, in Religion in the Emergence of Civilization: Çatalhöyük as a case study, ed. I. Hodder. Cambridge: Cambridge University Press.

Pilloud, M.A. \& C.S. Larson, 2011. 'Official' and 'practical' kin: inferring social and community structure from dental phenotype at Neolithic Çatalhöyük, Turkey. American Journal of Physical Anthropology 145(4), 51930.

Robin, C., 2003. New directions in Classic Maya household archaeology. Journal of Archaeological Research 11(4), 307-55.

Rollefson, G.O., 1997. Changes in architecture and social organization at Neolithic 'Ain Ghazal, in The Prehistory of Jordan II. Perspectives from 1997, eds. H.G.K. Gebel, Z. Kafafi \& G.O. Rollefson. Berlin: Ex oriente, 287308.

Rollefson, G.O., 2004. The character of LPPNB social organization, in Central Settlements in Neolithic Jordan, eds. H.D. Bienert, H.G.K. Gebel \& R. Neef. (Studies in Early Near Eastern Production, Subsistence and Environment 5.) Berlin: Ex oriente, 14555 .

Russell, N. \& L. Martin, 2005. The Çatalhöyük mammal remains, in Inhabiting Çatalhöyük: Reports from the 19951999 seasons, ed. I. Hodder. Cambridge/London: McDonald Institute for Archaeological Research/British Institute for Archaeology at Ankara, 3398.

Schwede, L.K., R.L. Blumberg \& A.Y. Chan, 2005. Complex Ethnic Households in America. New York (NY): Rowman \& Littlefield.

Sheets, P.D., H.F. Beaubien, M. Beaudry, et al., 1990. Household Aarchaeology at Ceren, El Salvador. Ancient Mesoamerica 1, 81-90.

Souvatzi, S., 2007. The identification of Neolithic households: unfeasible or just disregarded? in Building Communities: House, settlement and society in the Aegean and beyond, eds. R.C. Westgate, J. Whitley \& N.R.E. Fisher. (BSA Studies 15.) London: British School at Athens, 9-28.

Taylor, J., 2016. Excavations in the South Area, in Çatalhöyük 2016 Archive Report, ed. S.D. Haddow,
51-72. http://www.catalhoyuk.com/downloads/ Archive_Report_2016.pdf

Taylor, J., 2017. Excavations in the South Area, in Çatalhöyük 2016 Archive Report, ed. S.D. Haddow, 63-82. http://www.catalhoyuk.com/downloads / Archive_Report_2017.pdf

Thomas, J., 2015. House societies and the founding ancestors in Early Neolithic Britain, in Death Rituals, Social Order and the Archaeology of Immortality in the Ancient World, eds. C. Renfrew, M.J. Boyd \& I. Morley. Cambridge: Cambridge University Press, 13852.

Tung, B., 2013. Excavations in the North Area, in Çatalhöyük 2013 Archive Report, ed. S.D. Haddow, 8-44. http://www.catalhoyuk.com/downloads/ Archive_Report_2013.pdf

Tung, B., 2014. Excavations in the North Area, in Çatalhöyük 2014 Archive Report, ed. S.D. Haddow, 13-42. http://www.catalhoyuk.com/downloads/ Archive_Report_2014.pdf

Tung, B., 2015. Excavations in the North Area, in Çatalhöyük 2015 Archive Report, ed. S.D. Haddow, 17-34. http://www.catalhoyuk.com/downloads/ Archive_Report_2015.pdf

Tung, B., 2016. Excavations in the North Area, in Çatalhöyük 2016 Archive Report, ed. S.D. Haddow, 1750. http://www.catalhoyuk.com/downloads / Archive_Report_2016.pdf

Turner, C.G. II \& L. Lofgren, 1966. Household size of prehistoric Western Pueblo Indians. Southwestern Journal of Anthropology 22(2), 117-32.

Twiss, K.C., 2007. Home is where the hearth is: food and identity in the Neolithic Levant, in The Archaeology of Food and Identity, ed. K.C. Twiss. (Center for Archaeological Investigations Occasional paper 34.) Carbondale (IL): Southern Illinois University, 50-68.

Twiss, K.C., 2008. Transformations in an early agricultural society: feasting in the southern Levantine PrePottery Neolithic. Journal of Anthropological Archaeology 27, 418-42.

Twiss, K.C., 2012. The archaeology of food and social diversity. Journal of Archaeological Research 20, 357-95.

Uzdurum, M., 2013. Aşıklı Höyük Yerleşmesinde Ateş Yerleri ve Kullanım [Fire locations and usage at Aşıkl Höyük]. Masters thesis, Istanbul University.

Verdery, A.M., B. Entwisle, K. Faust \& R.R. Rindfuss, 2012. Social and spatial networks: kinship distance and dwelling unit proximity in rural Thailand. Social Networks 34(1), 112-27.

Watson, P.J., 1982. Archaeological Ethnography in Western Iran. (Viking Fund Publications 57.) Tucson (AZ): WennerGren Foundation for Anthropological Research.

Wilk, R. \& W.L. Rathje, 1982. Household archaeology. American Behavioral Scientist 25, 617-39.

Wright, K.I., 2014. Domestication and inequality? Households, corporate groups and food processing tools at Neolithic Çatalhöyük. Journal of Anthropological Archaeology 33, 1-33. 


\section{Author biography}

Ian Kuijt is a Full Professor in the Anthropology Department, University of Notre Dame. His research interests include small-scale village and household life in the Near East, Ireland and prehistoric western North America. Publications include Transformation by Fire: The archaeology of cremation in cultural context (2014, edited with C. Quinn \& G. Cooney). 